\title{
Examination of the Mechanical, Corrosion, and Tribological Behavior of Friction Stir Welded Aluminum Alloy AA8011
}

\author{
R. Arun Kumara, R. Vaira Vignesh ${ }^{\mathrm{b}}$, N. Srirangarajalua, \\ R. Padmanaban ${ }^{b}$
}

Aluminum alloy AA8011 is emerging as a promising material for modern engineering applications in which improved tensile strength, hardness, corrosion-resistance, and wear-resistance of materials are required. Typically, AA8011 alloys are utilized in air-conditioning ducts and heat exchanger fins in ships, leisure boats, luxury vessels, workboats, fishing vessels, and patrol boats. However, the conventional welding of AA8011 is a challenging procedure. In this context, this paper focuses on the development of an effective solid-state welding methodology for AA8011 alloy welding. The AA8011 alloy was friction stir welded by varying the tool rotation speed, traverse speed, and shoulder diameter.

\section{KEY WORDS}

$\sim$ FSW

$\sim$ Aluminum alloy

$\sim$ Corrosion

$\sim$ Tensile

Fractography

a. Anna University, Madras Institute of Technology, Department of Production Technology, Chennai, India

e-mail: rarunkcemit@gmail.com

b. Amrita School of Engineering, Department of Mechanical Engineering, Coimbatore, Amrita Vishwa Vidyapeetham, India

e-mail: r.vairavignesh@gmail.com

doi: 10.7225/toms.v10.n01.002

This work is licensed under (cc) BY

Received on: Oct 7, 2020 / Revised on: Jan 27, 2021 / Accepted on: Feb 7, 2021 / Published: Apr 20, 2021
The microhardness, tensile strength, joint efficiency, elongation, corrosion rate, and wear rate of the friction stir welded specimens were compared with the base material. Fractography analysis was conducted after the tensile test and surface morphology analysis after corrosion and wear tests, using scanning electron microscopy. The compositional elements in the corroded and worn section of the specimens were analyzed using energydispersive X-ray spectroscopy. Based on the joint efficiency as a primary constraint, the optimum process parameters for friction stir welding of aluminum alloy AA8011 have been established as follows: tool rotation speed of $1200 \mathrm{rpm}$, tool traverse speed of $45 \mathrm{~mm} / \mathrm{min}$, and tool shoulder diameter of $21 \mathrm{~mm}$.

\section{INTRODUCTION}

Aluminum alloys are widely used in many industries due to their high strength to weight ratio, good ductility, and corrosion resistance (Vasudevan and Doherty, 2012). Typically, AA8011 alloys are utilized in air-conditioning ducts and heat exchanger fins in ships, leisure boats, luxury vessels, workboats, fishing vessels, and patrol boats (Magibalan et al., 2018; Mishra, 2020; Cui et al., 2019; Mandal, 2017). However, welding of aluminum alloys using the conventional welding process is a serious limitation. During conventional welding of aluminum alloys, weldments rapidly oxidize, resulting in porosity, incomplete fusion, and cracks (Palani et al., 2018a; 2018b; Nandan et al., 2008; Ghetiya et al., 2016; Davidson and Neelakrishnan, 2018). This leads to poor joint efficiency, as well as poor corrosion, and tribological 
properties. Hence, aluminum alloys should be joined in solidstate to overcome the rapid oxidation phenomenon and improve the desired properties (Akca and Gürsel, 2016).

In the solid-state welding process, the material being welded is heated to less than the melting temperature of the base material and joined without any filler material or inert atmosphere (Vora and Badheka, 2019). Only a handful solid-state welding methods include friction welding, friction stir welding, explosion welding, forge welding, hot pressure welding, and ultrasonic welding (Akinlabi and Mahamood, 2020). Comparatively lower residual stresses and heat-affected zones in the weldments make friction stir welding a distinct and promising methodology to produce sound joints in aluminum alloy (Nandan et al., 2008; Midling et al., 1998; Mishra and Ma, 2005).

In friction stir welding, a non-consumable rotating tool is traversed along the joint line of the plates being welded by the action of the axial force (Midling et al., 1998; Wahid et al., 2016). The traverse of the rotating tool under normal load generates frictional heat, which plasticizes the material and enables the creation of a sound joint in the plasticized state (Vaira Vignesh et al., 2016; 2019). However, excess or insufficient heat generation and poor or turbulent material flow result in observable defects such as voids, insufficient penetration, lack of fusion, surface lack of fill, root-flow defect, nugget collapse, surface galling, and scalloping in the friction stir weldments (Vaira Vignesh, 2018a; 2018b). The defects could be reduced or eliminated through the proper choice of friction stir welding process parameters (Vaira Vignesh and Ramasamy, 2017).

Earlier studies suggest that tool rotation speed, tool traverse speed (welding speed), and tool profile (shoulder diameter, pin profile) are process parameters that have the highest impact on friction stir welding (Palani et al., 2018a; 2018b; Nandan et al., 2008; Ghetiya et al., 2016; Davidson and Neelakrishnan, 2018; Wahid et al., 2016; Vaira Vignesh et al., 2018a; 2018b; 2017). In this study, aluminum alloy AA8011 is friction stir welded by varying the friction stir welding process parameters, namely tool rotation speed, welding speed, and tool shoulder diameter. Joint strength, elongation and efficiency, corrosion rate, and wear rate of the weldments were evaluated. Tensile specimen fractography, the surface morphology of corrosion test specimens and wear test specimens were analyzed using a high-resolution scanning electron microscope. The elemental composition of the corroded and worn region was analyzed using energy dispersive x-ray electron spectroscopy. Models based on a hybrid quadraticradial basis function were developed to correlate the friction stir welding process parameters with weldment properties (strength, elongation, efficiency of the joints, corrosion rate and wear rate). The influence of the process parameters on the evolution of properties was described. In addition, optimum process parameters for friction stir welding of aluminum alloy AA8011 was established.

\section{MATERIALS AND METHODS}

\subsection{Materials}

The composition of the AA8011 aluminum alloy is given in Table 1. The alloy plate was received in the annealed condition. The plate was cut into $5 \mathrm{~mm}$ thick, $50 \mathrm{~mm}$ wide, and $150 \mathrm{~mm}$ long work pieces. Plate sides were milled and ground to ensure their proper clamp in the fixture.

Table 1.

Composition of aluminum alloy AA8011.

\begin{tabular}{lllllllllll} 
Element & $\mathrm{Al}$ & $\mathrm{Fe}$ & $\mathrm{Si}$ & $\mathrm{Mn}$ & $\mathrm{Zn}$ & $\mathrm{Cu}$ & $\mathrm{Ti}$ & $\mathrm{Cr}$ & $\mathrm{Mg}$ & other \\
\hline Composition & $97.3-$ & $0.60-1$ & $0.50-$ & $\leq 0.20$ & $\leq 0.10$ & $\leq 0.10$ & $\leq 0.080$ & $\leq 0.050$ & $\leq 0.050$ & $\leq 0.15$ \\
& 98.9 & & 0.90 & & & & & & &
\end{tabular}

\subsection{Design of Experiments}

This study emphasizes the role of friction stir welding process parameters, namely, tool rotation speed, welding speed, and tool shoulder diameter, on weldment properties. The chosen level of friction stir welding process parameters is given in Table 2. Process parameters were varied at three levels as per BoxBehnken design and the experimental layout for friction stir welding trials is shown in Table 3.

\subsection{Friction Stir Welding}

The work pieces were degreased with acetone and clamped in the fixture. The friction stir welding trials were performed in a numerically-controlled vertical milling center, as shown in the experimental layout in Table 3. A dwell time of $60 \mathrm{sec}$ was selected for each friction stir welding trial. The friction stir welding tool was made from high-speed steel having the hardness of $65 \mathrm{HRC}$. 
Table 2.

Chosen levels of friction stir welding process parameters.

\begin{tabular}{llll} 
Sl. & Tool rotation speed $(\mathbf{r p m})$ & Welding speed $(\mathbf{m m} / \mathbf{m i n})$ & Tool shoulder diameter $(\mathbf{m m})$ \\
\hline Level $\mathbf{1}$ & 1200 & 30 & 15 \\
\hline Level 2 & 1400 & 45 & 18 \\
\hline Level 3 & 1600 & 60 & 21 \\
\hline
\end{tabular}

Table 3.

Wear test parameters.

\begin{tabular}{lll} 
SI. & Parameter & Value \\
\hline 1 & Speed & $200 \mathrm{rpm}$ \\
\hline 2 & Time & 15 minutes \\
\hline 3 & Force & $9.81 \mathrm{~N}$ \\
\hline 4 & Track diameter & $60 \mathrm{~mm}$ \\
\hline
\end{tabular}

\subsection{Microhardness}

Specimens were cut from the base material and weldments and polished in compliance with the ASTM E3-11 standard. Vicker's microhardness of the specimens was measured using a microhardness tester (UHL, as prescribed by the ISO 6507 standard). The specimens were indented using a diamond indentor, by applying the normal load of 500-gram force for $15 \mathrm{~s}$.

\subsection{Tensile Strength}

Tensile test was performed to assess the ultimate tensile strength of the friction stir welded specimens. Two specimens were machined from each friction stir welded work piece using abrasive waterjet machining. The tensile test was performed in a computerized tensile test machine (Tinius Olsen) in keeping with the ASTM B557-10 standard. The stress-strain graph was plotted and analyzed in the dedicated software.

\subsection{Wear Rate}

The weldment wear rate was assessed based on the wear test conducted in a pin-on-disc tribometer. In the pin-on-disc tribometer, the pin slides across the disc at a particular velocity, under an axial load. Uniform contact between the pin and the disc was maintained using the suitable lever arrangement. 10 $\mathrm{mm} \times 10 \mathrm{~mm}$ specimens were cut from the weldments and mounted in the hollow steel tube using a cold setting compound. The specimens were slid against the hardened steel EN316. The wear test parameters were chosen as follows: the load of $9.81 \mathrm{~N}$, the sliding velocity of $0.628 \mathrm{~m} / \mathrm{s}$, and the sliding distance of 565 $\mathrm{m}$. The mass of the specimen before and after the wear test was measured using a precision balance having the readability of $0.0001 \mathrm{~g}$.

\subsection{Corrosion}

The corrosion test was performed by exposing small sections of the welded material to the test medium. The specimens were polished and degreased with acetone before the corrosion test. The specimens were immersed in an accelerated corrosion test medium, which was prepared by mixing $100 \mathrm{ml}$ of distilled water, $10 \mathrm{~g}$ of sodium chloride $(\mathrm{NaCl})$, and $5 \mathrm{ml}$ of acetic acid (20:2:1). The $\mathrm{pH}$ of the medium was 2.0, which was measured using a $\mathrm{pH}$ meter having the sensitivity of 0.1 . The temperature of the medium was maintained at $30^{\circ} \mathrm{C}$ using a temperature-controlled water bath. The mass loss of the material was measured after the immersion period and the corrosion rate was calculated. The mass of the specimen before and after the corrosion test was weighed using a precision weighing balance having the readability of $0.0001 \mathrm{~g}$.

\subsection{Characterization}

Tensile test specimen fractograph, the surface morphology of the corroded specimens, and the surface morphology of the worn specimens were observed under a high-resolution scanning electron microscope. The elemental composition of the corroded and worn out specimens were analyzed using energydispersive X-ray spectroscopy.

\subsection{Quadratic - Radial Basis Function Model}

Conventionally, the relationship between process parameters and response variables is modeling using the mathematical regression equations (linear, quadratic, cubic, or polynomial function). However, the serious limitation is that the regression equation could not model the complex non-linearity characteristics of response variables (Ilangovan et al., 2017; Ashwin et al., 2019; Anil Kumar et al, 2019; Murugan et al., 2018). 
Recently, researchers have started working on the development of soft computing techniques like fuzzy-logic and artificial neural networks to associate process parameters with response variables that have non-linearity characteristics (Malekimoghadam and Icardi, 2019; Shehabeledeen et al., 2019; Barath et al., 2018). In this study, the authors have developed hybrid models integrating the quadratic function and radial basis function (mono-layered artificial neural network) to associate process parameters with response variables. The details of model development are discussed elsewhere (Vaira Vignesh et al., 2018c).

\section{RESULTS AND DISCUSSION}

\subsection{Microhardness}

The average Vicker's microhardness of the base material and friction stir welded specimens is presented in Figure 1. The average microhardness of base material was $40.78 \mathrm{HV}$. The plot indicates that the microhardness of the majority of friction stir welded specimens is lower than the microhardness of the base material. Among the friction stir welded specimens, specimen FSW03 had the average microhardness of $40.56 \mathrm{HV}$, which is closer to that of the base material. The microhardness of specimens FSW08 and FSW06 is closer to the microhardness of the base material. Given that specimen FSW07 had pin-holes in the weldments it had the lowest microhardness of $27.78 \mathrm{HV}$, which is $32 \%$ less than the microhardness of the base material.

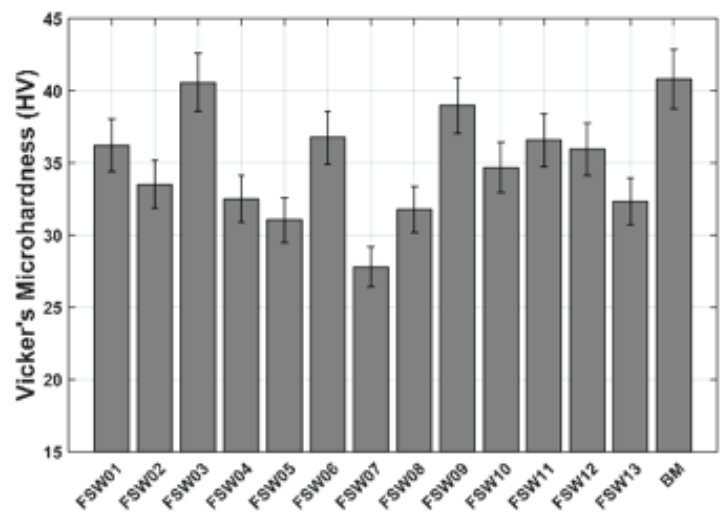

Figure 1.

Microhardness of the base material and friction stir welded specimens.

\subsection{Elongation, Tensile Strength, Joint Efficiency}

The tensile test was performed on the base material and friction stir welded specimens in a computerized tensile testing machine, and the stress-strain graph was plotted. The percentage elongation of the specimens was calculated using equation (1).
$\%$ Elongation $=\frac{\Delta l}{l} \cdot 100$

where $\Delta /$ is the change in length, $/$ is gauge length.

The average percentage elongation of the base material and friction stir welded specimens in the course of the tensile test is shown in Figure 2 (a). The base material had the highest elongation of $22.88 \%$, whereas specimen FSW12 had the lowest elongation of $5.63 \%$. Among the welded specimens, specimen FSW11 exhibited high elongation of $14.48 \%$. The results indicate that the percentage elongation decreases after the welding process.

The average ultimate tensile strength of the base material and friction stir welded specimens is shown in Figure 2 (b). The base material exhibited the high tensile strength of $111.84 \mathrm{MPa}$. The tensile strength of all friction stir welded specimens is lower than that of the base material. Specimen FSW11 had the highest tensile strength of all friction stir welded specimens, scoring 62.20 MPa. The tensile strength of specimens FSW02 and FSW03 is similar to the tensile strength of specimen FSW11. Figure 3 (a) shows the cracks, Figure 3 (b) shows the deformation zone and Figure 3 (c) shows the quasi-cleavage dimples in the fractograph of specimen FSW11. The presence of a comparatively higher deformation zone and the absence of voids are indicative of the higher tensile strength of specimen FSW11. The fractograph of specimen FSW12 is shown in Figure 3 (d), Figure 3 (e), and Figure 3 (f) at various magnifications. Figure 3 (d) shows the transgranular cracks and the secondary crack, Figure 3 (e) shows the presence of more tearing rides and voids, and Figure 3 (f) shows the lesser deformation zone and wide voids. This indicates the low tensile strength of specimen FSW12.

The joint efficiency is the numerical value which is the ratio of the strength of the weld and the strength of the base material. The joint efficiency is one of the crucial aspects to introduce the safety factor in the welding process. The percentage joint efficiency of the joints was calculated using equation (2).

Joint efficiency $(\%)=\frac{\sigma_{F S W}}{\sigma_{B M}} \cdot 100$

where $\sigma_{F S W}$ is the strength of the weld, $\sigma_{B M}$ is the strength of the base material.

The joint efficiency of friction stir welded specimens is shown in Figure 2 (c). The results indicate that the joint efficiency of all friction stir welded specimens exceeds 30\%. However, joint efficiency greater than $50 \%$ indicates sound weldments. Specimens FSW01, FSW02, FSW03, FSW06, FSW08, and FSW11 had the joint efficiency greater than 50 , whereas specimens 
a)

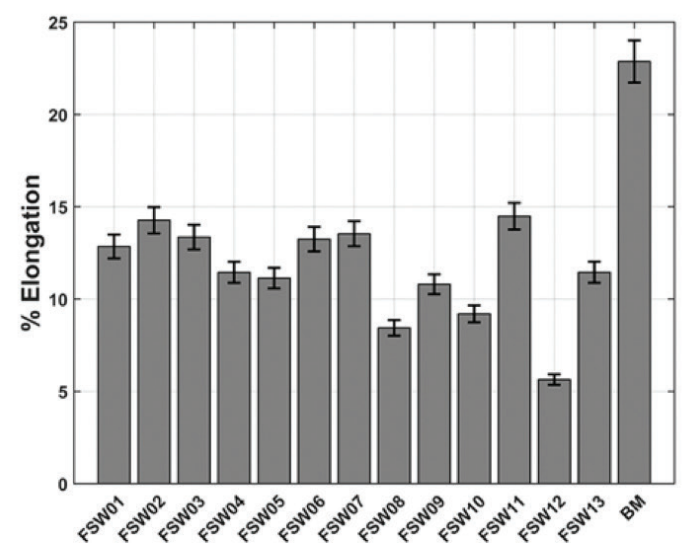

c)

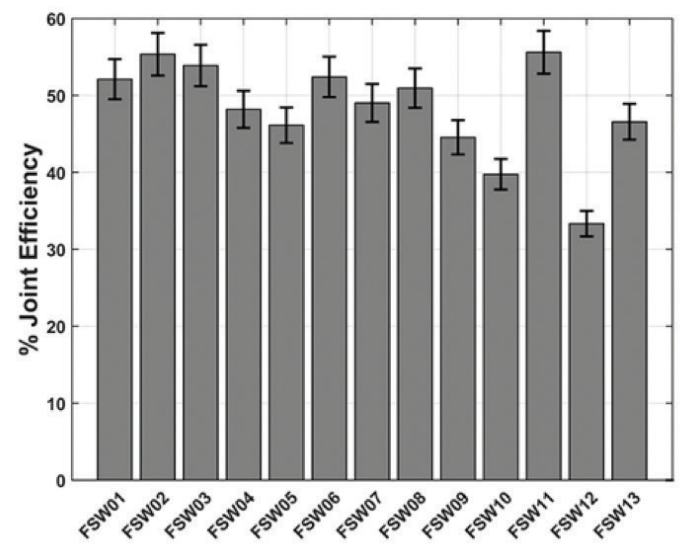

b)

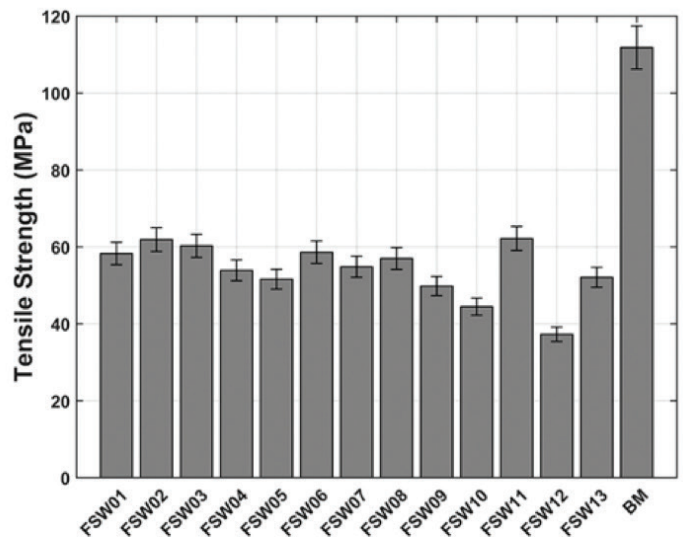

Figure 2.

(a) \% elongation; (b) ultimate tensile strength; (c) joint efficiency of the base material and friction stir welded specimens.

FSW04, FSW05, FSW07, FSW09, FSW10, FSW12, FSW13 had joint efficiency lower than 50\%. Among friction stir welded specimens, specimen FSW11 had the highest joint efficiency of 55.62\% and specimen FSW12 had the lowest joint efficiency of 33.34\%.

\subsection{Immersion Corrosion}

The corrosion rate of the base material and friction stir welded specimens was determined based on the immersion corrosion test. The specimens were immersed in the accelerated corrosion environment and their mass loss was calculated. The corrosion rate of the specimens was calculated using equation (3).

$$
\text { Corrosion rate }=\frac{K \cdot \Delta M}{\rho \cdot A_{e} \cdot T}
$$

where $K$ is the conversion factor $=87.6, \Delta M$ is mass loss, $\rho$ is density, $A_{e}$ is exposure area, $T$ is immersion time.

The graphical representation of the corrosion rate of the base material and the friction stir welded specimens is shown in Figure 4. The corrosion rate of all friction stir welded specimens was lower than the base material corrosion rate of $11.320 \mu \mathrm{m} /$ year. However, specimen FSW06 had the corrosion rate of 11.215 $\mu \mathrm{m} /$ year, which is closer to the corrosion rate of the base material. The surface of specimen FSW05 had a scaly appearance, as shown in Figure 5 (a), Figure 5 (b), and Figure 5 (c). The corrosion rate of specimen FSW05 was $1.414 \mu \mathrm{m} /$ year, which is $~ 87.5 \%$ less than that of the base material. Specimen FSW06 had a scaly appearance with many corrosion pits, as observed in Figure 5 (d), Figure (e), and Figure 5 (f). The elemental composition of the corroded area of specimens FSW05 and FW06 is shown in Figure 6 (a) and Figure 6 (b) respectively. The major elements in the corroded surface were $\mathrm{Al}, \mathrm{Si}, \mathrm{O}$, and Fe. However, a peak corresponding to $\mathrm{Na}$ and $\mathrm{Cl}$ was observed in minor counts. 
a)

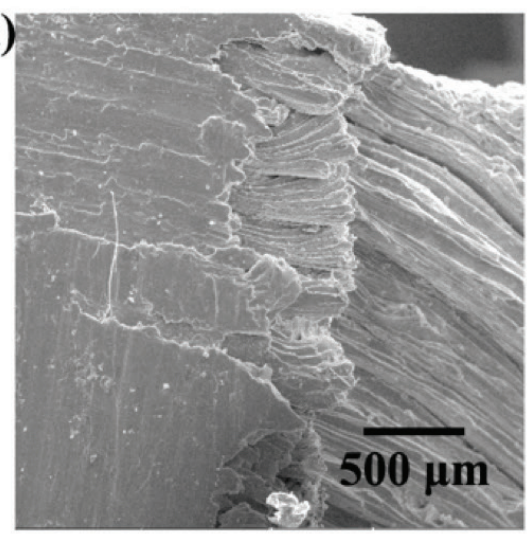

d)

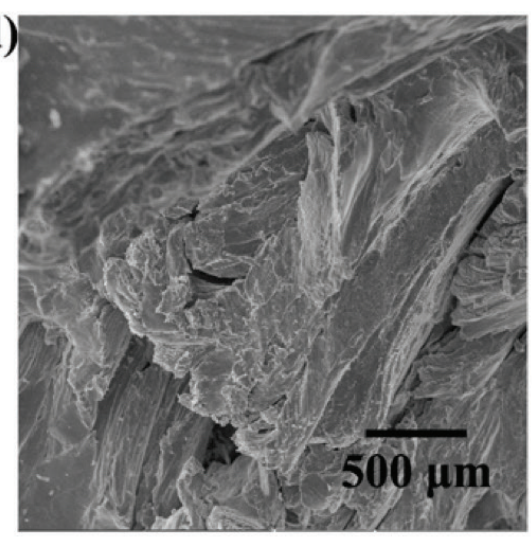

b)

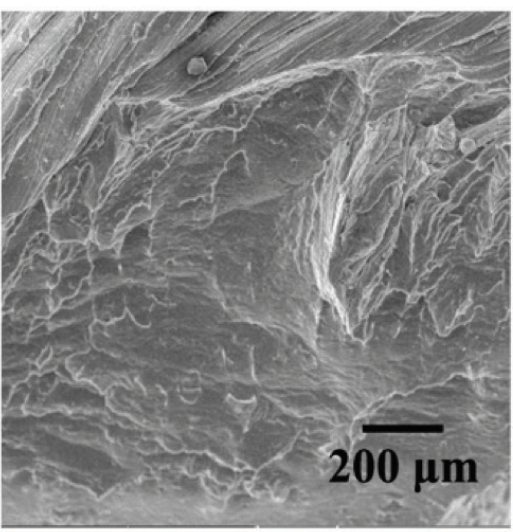

e)

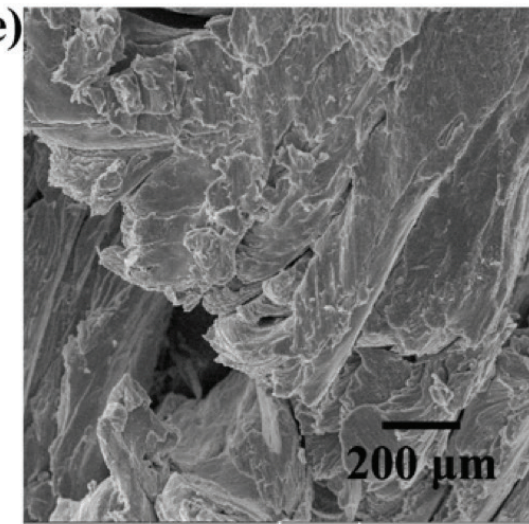

c)

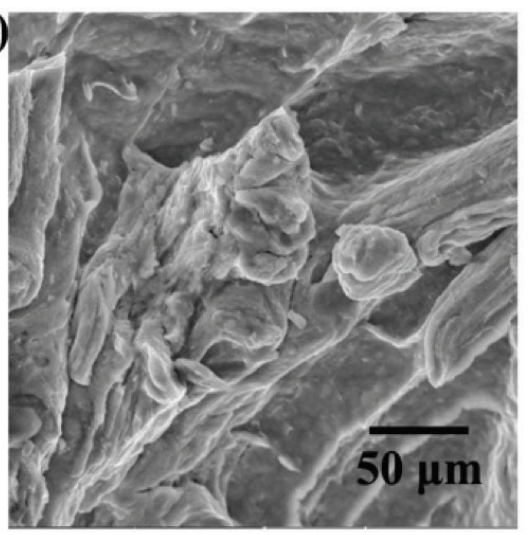

f )

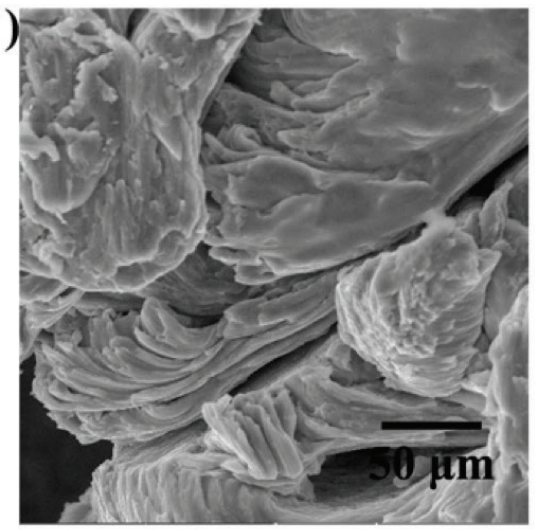

Figure 3.

Fractograph of $(a, b, c)$ Specimen FSW11; $(\mathrm{d}, \mathrm{e}, \mathrm{f})$ Specimen FSW12.

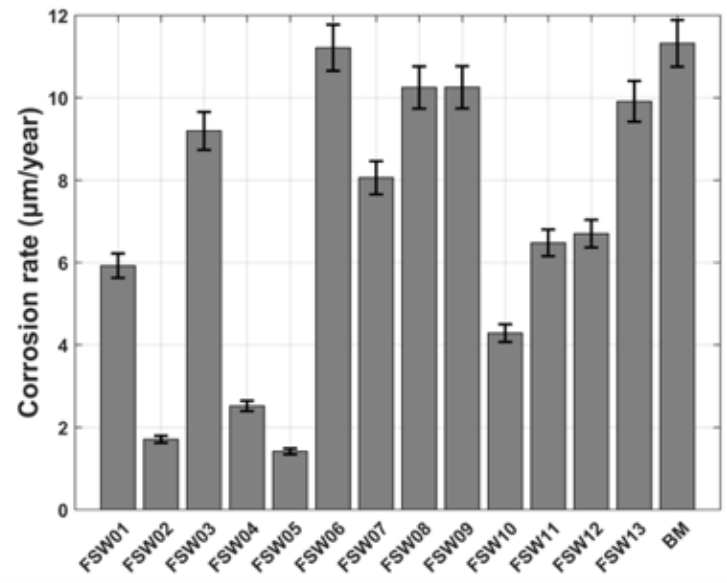

Figure 4.

Corrosion rate of the base material and friction stir welded specimen. 
a)

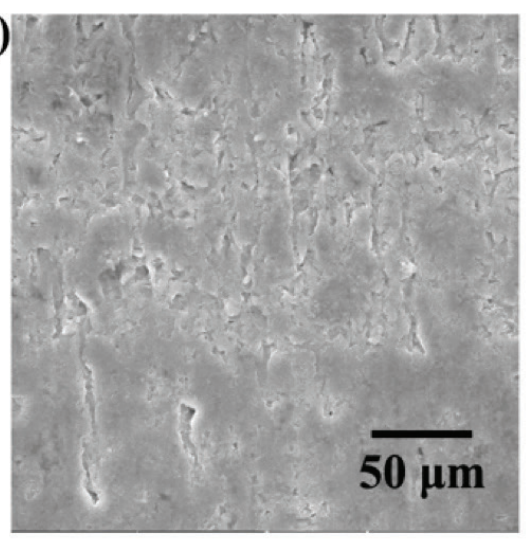

b)

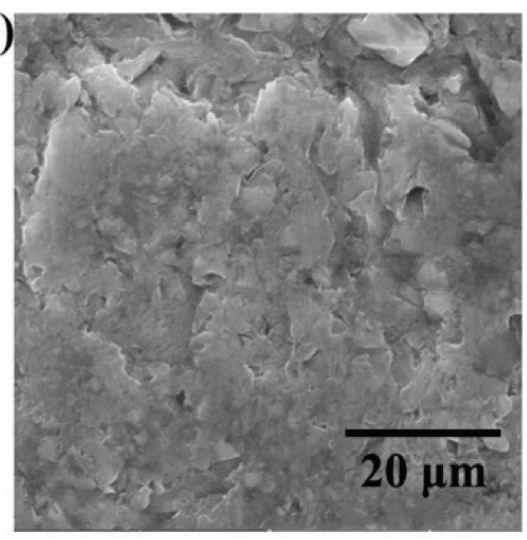

d)

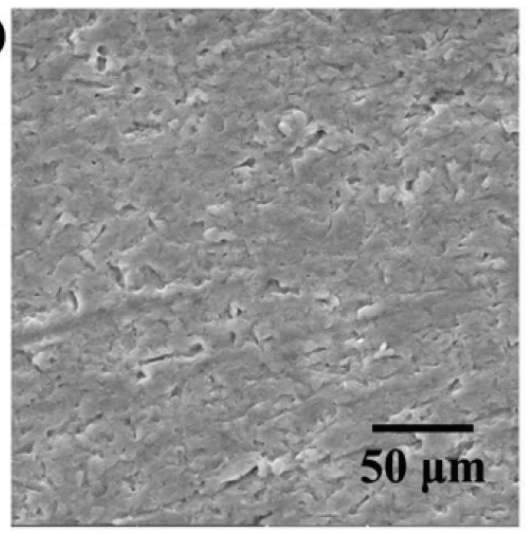

e)

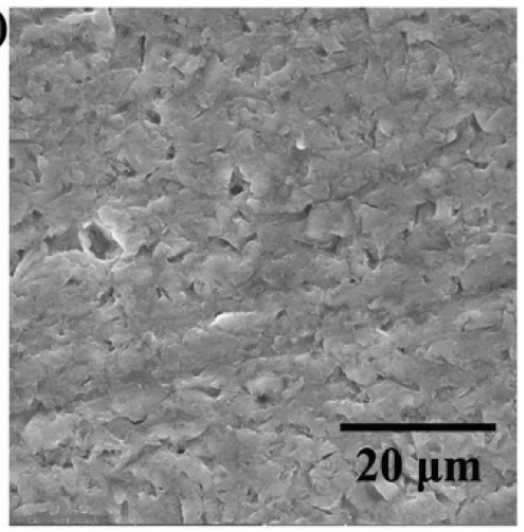

c)

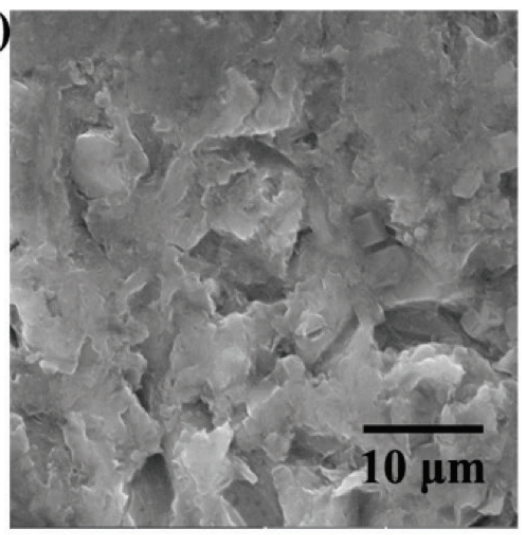

f)

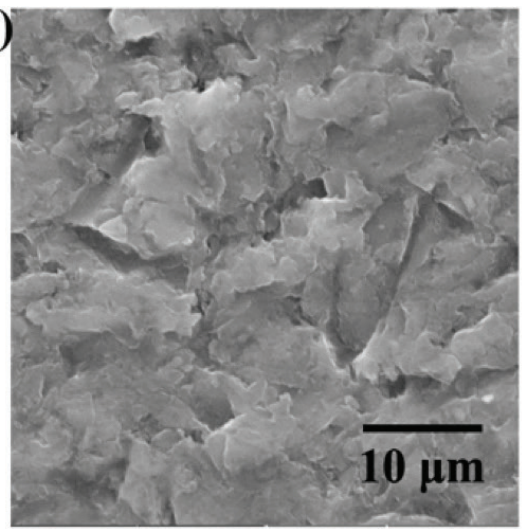

Figure 5.

Surface morphology of the corroded region $(\mathrm{a}, \mathrm{b}, \mathrm{c})$ Specimen FSW05; (d,e,f) Specimen FSW06.

a)

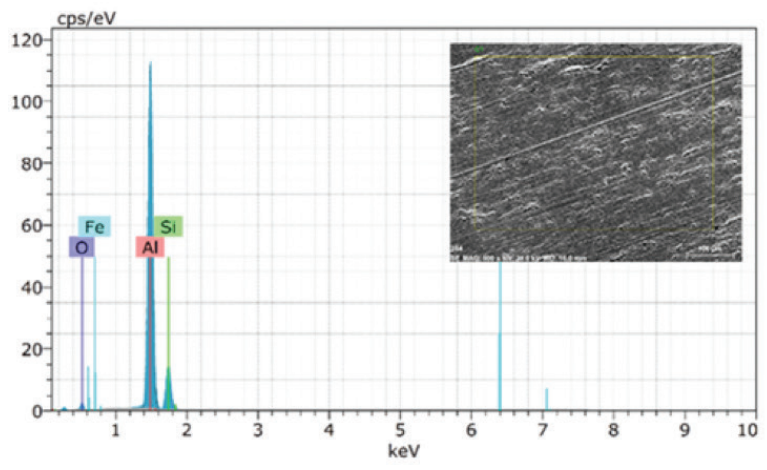

b)

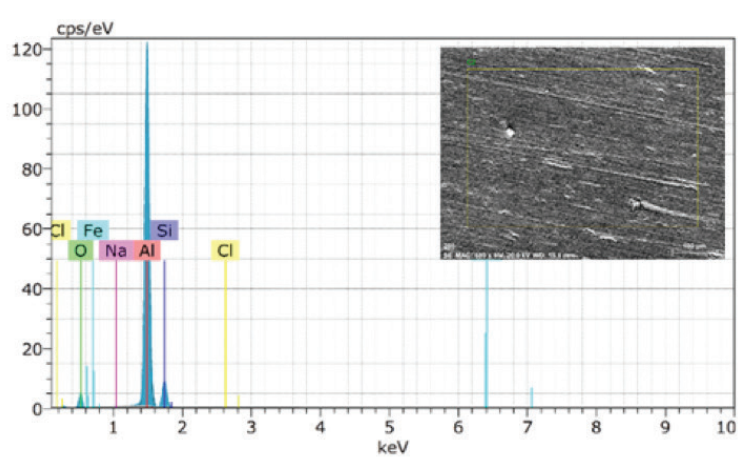

Figure 6.

Elemental composition of the corroded region (a) Specimen FSW05; (d) Specimen FSW06. 


\subsection{Wear Rate and Coefficient of Friction}

Wear test was carried out in the pin on disk wear test machine. The wear rate of the specimen was calculated using equation (3). Experimental results are presented as a bar chart in Figure 7 (a).

Wear rate $=\frac{\Delta M}{N_{f} \cdot L}$

where $\Delta M$ is mass loss, $N_{f}$ is normal force, $L$ is sliding distance, $F_{f}$ is frictional force.

The wear rate of the base material and friction stir welded specimens is shown in Figure 7 (a). The wear rate of the base material was measured to be $3.24 \times 10^{-7} \mathrm{~g} / \mathrm{Nm}$. The experimental results indicate that the wear rate varied between $1 \times 10^{-7} \mathrm{~g} / \mathrm{Nm}$ and $5 \times 10^{-7} \mathrm{~g} / \mathrm{Nm}$ in most of the friction stir welded specimens. Figure 8 (a) shows feeble wear tracks, Figure 8 (b) shows wear debris, and Figure 8 (c) shows the delamination and crater on the worn-out specimen FSW05. In line with the observations, the low wear rate of $1.26 \times 10^{-7} \mathrm{~g} / \mathrm{Nm}$ was recorded for specimen FSW05. On the other hand, specimen FSW13 had the highest wear rate of $7.39 \times 10^{-7} \mathrm{~g} / \mathrm{Nm}$, which is $\sim 56 \%$ higher than the wear rate of the base material. Figure 8 (d) shows deep continuous grooves, Figure 8 (e) and Figure 8 ( $\mathrm{f}$ ) show the wear debris of specimen FSW13.

The elemental composition of the worn-out region of specimens FSW05 and FSW13 is shown in Figure 9 (a) and Figure 9 (b) respectively. The significant peaks were obtained for $\mathrm{Al}$, $\mathrm{Si}, \mathrm{O}$, and Fe elements. Therefore, the wear debris consists of the chipped base material in its original and oxidized state. The coefficient of friction was derived from the ratio of frictional force to normal force, as given by equation (4). The average coefficient of friction for the base material and the friction stir welded specimens is shown in Figure 7 (b).

Coefficient of friction $=\frac{F_{f}}{N_{f}}$

The average coefficient of friction of the base material and of the friction stir welded specimens is shown in Figure 7 (b). The coefficient of friction of friction stir welded specimens is significantly higher than the coefficient of friction of the base material. The coefficient of friction is similar in all friction stir welded specimens.

\subsection{Quadratic - Radial Basis Function Model}

Equation (6), Equation (7), Equation (8), Equation (9), Equation (10), and Equation (11) are hybrid models for predicting the microhardness, tensile strength, joint efficiency, elongation, corrosion rate and wear rate of the friction stir welded specimens, developed in the Matlab ${ }^{\oplus}$ technical computing environment. In the developed model, coded levels of process parameters were used (lower limit being -1 and the upper limit is +1 ).

\section{Microhardness}

$$
\begin{aligned}
& =19.1327+2.10427 \cdot S D-2.17961 \cdot R S \\
& +4.74534 \cdot W S+1.24475 \cdot S D \cdot T R S \\
& -0.590218 \cdot S D \cdot W S-0.504604 \cdot T R S \cdot W S+R B F_{1}
\end{aligned}
$$

\section{Tensile strengtht}

$$
\begin{aligned}
& =41.4010+26.7096 \cdot S D+1.75205 \cdot T R S \\
& +28.8839 \cdot W S+1.4275 \cdot S D \cdot T R S \\
& -2.14648 \cdot S D \cdot W S+9.53883 \cdot T R S \cdot W S+R B F_{2}
\end{aligned}
$$

\section{Joint efficiency}

$=36.9912+23.8898 \cdot S D+1.5692 \cdot$ TRS

$+7.86134 \cdot W S+1.275 \cdot S D \cdot T R S$

$-6.21636 \cdot S D \cdot W S+4.23177 \cdot T R S \cdot W S+R B F_{3}$

\section{Elongation}

$$
\begin{aligned}
& =22.0013-0.89828 \cdot S D-4.82944 \cdot T R S \\
& +1.7417 \cdot W S-1.23181 \cdot S D \cdot T R S \\
& -2.33823 \cdot S D \cdot W S+4.81474 \cdot T R S \cdot W S+R B F_{4}
\end{aligned}
$$

\section{Corrosion rate}

$$
\begin{aligned}
& =-18.2103+3.50569 \cdot S D-24.7966 \cdot T R S \\
& -14.0959 \cdot W S+1.73561 \cdot S D \cdot T R S \\
& +3.11864 \cdot S D \cdot W S+9.55625 \cdot T R S \cdot W S+R B F_{5}
\end{aligned}
$$

\section{Wear rate}

$$
\begin{aligned}
& =-4.198 E^{-07}+8.4711 E^{-08} \cdot S D+5.5492 E^{-07} \cdot T R S \\
& -4.567 E^{-07} \cdot W S-1.098 E^{-08} \cdot S D \cdot T R S \\
& +1.187 E^{-07} \cdot S D \cdot W S-4.0228 E^{-08} \cdot T R S \cdot W S+R B F_{6}
\end{aligned}
$$


a)

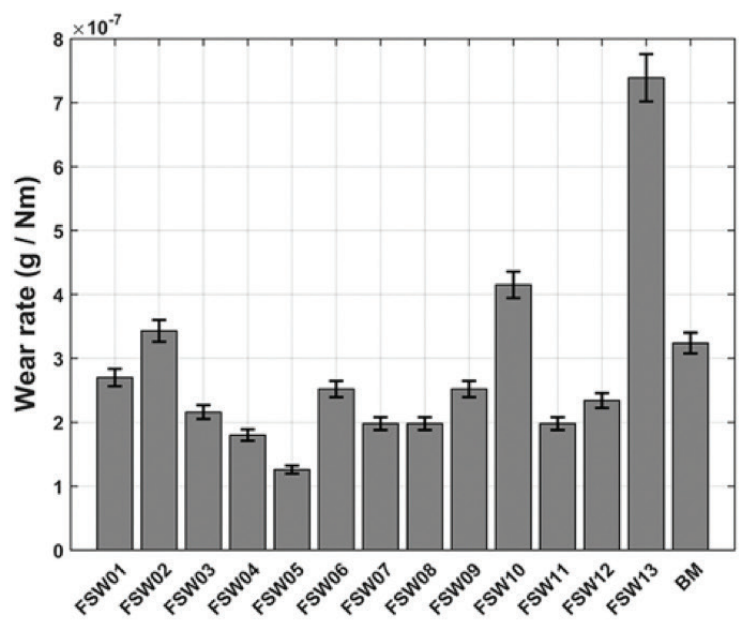

b)

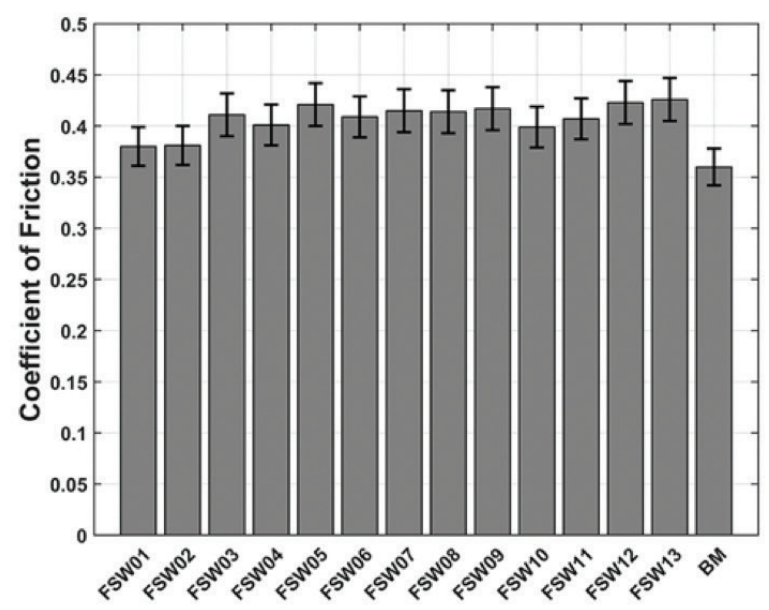

Figure 7.

(a) Wear rate; (b) Coefficient of friction of the base material and friction stir welded specimens.

a)

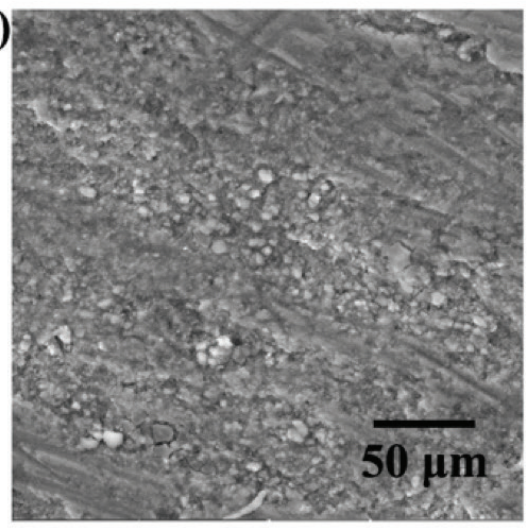

d)

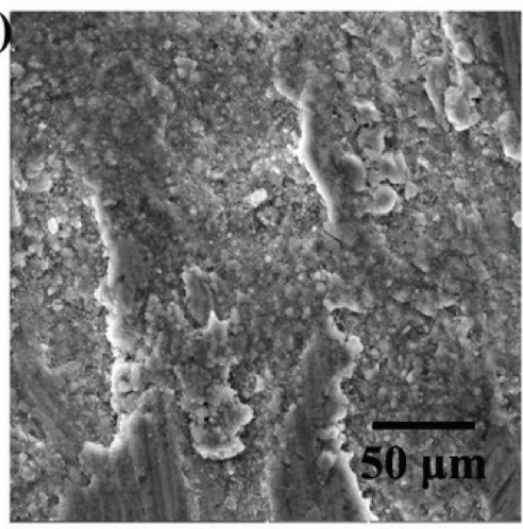

b)

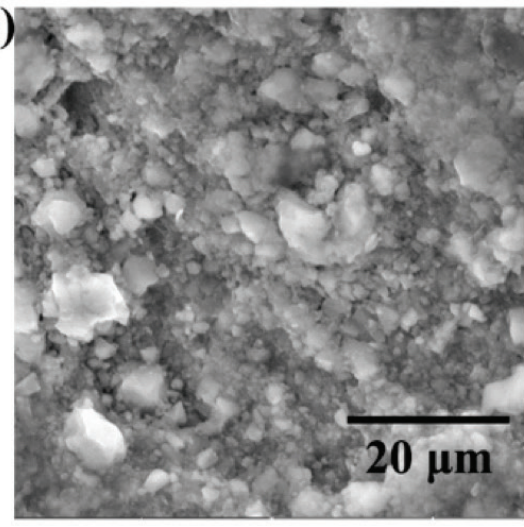

e)

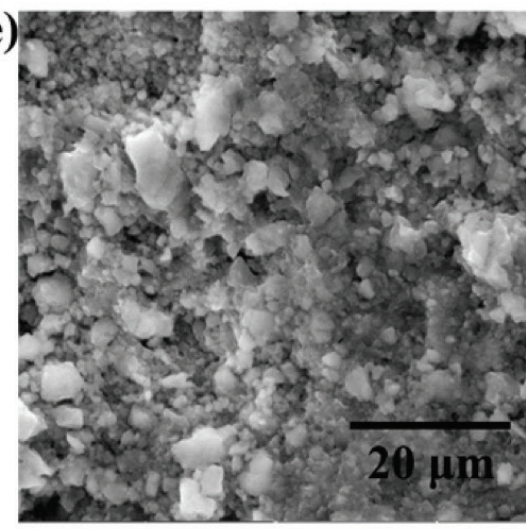

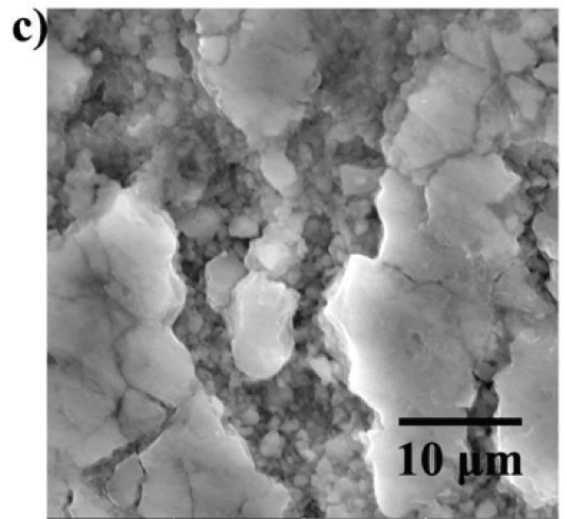

f)

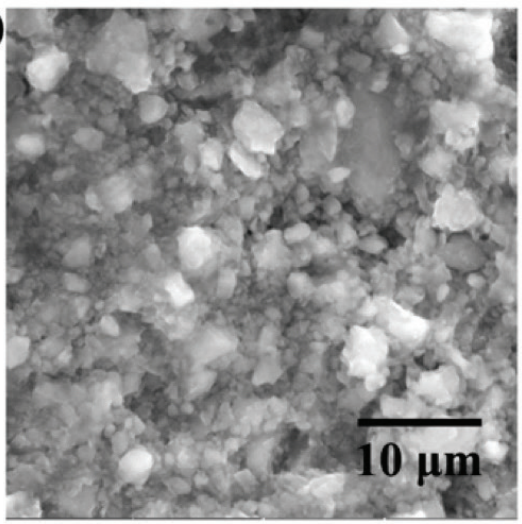

Figure 8.

Surface morphology of the corroded region $(a, b, c)$ Specimen FSW05; (d,e,f) Specimen FSW13. 
a)

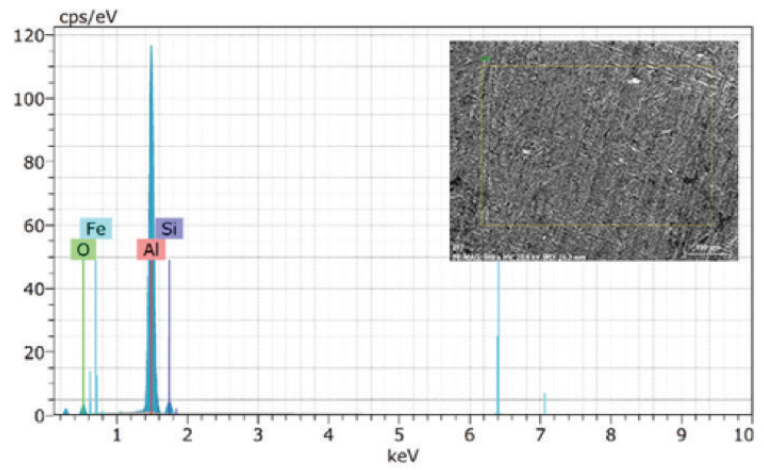

b)

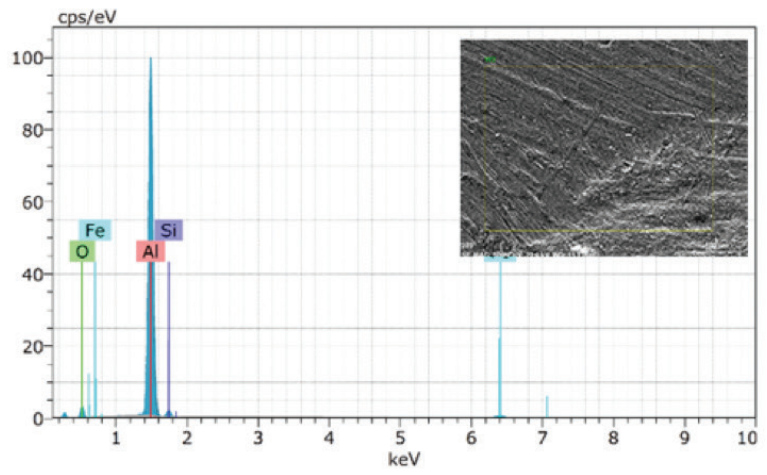

Figure 9.

Elemental composition of the corroded region (a) Specimen FSW05; (d) Specimen FSW13.

Table 4.

Microhardness, tensile strength, \% elongation, corrosion rate and wear rate of friction stir welded AA8011 alloy.

\begin{tabular}{|c|c|c|c|c|c|c|c|c|c|}
\hline $\begin{array}{l}\text { Specimen } \\
\text { code }\end{array}$ & $\begin{array}{l}\text { Tool } \\
\text { rotation } \\
\text { speed }\end{array}$ & $\begin{array}{l}\text { Welding } \\
\text { speed }\end{array}$ & $\begin{array}{l}\text { Shoulder } \\
\text { diameter }\end{array}$ & $\begin{array}{l}\text { Tensile } \\
\text { strength }\end{array}$ & Elongation & $\begin{array}{l}\text { Joint } \\
\text { efficiency }\end{array}$ & $\begin{array}{l}\text { Average } \\
\text { (HV) }\end{array}$ & Wear rate & $\begin{array}{l}\text { Corrosion } \\
\text { rate }\end{array}$ \\
\hline & rpm & $\mathrm{mm} / \mathrm{min}$ & $\mathrm{mm}$ & $\mathrm{MPa}$ & $\%$ & $\%$ & & (g/Nm) & ( $\mu \mathrm{m} /$ year) \\
\hline FSW01 & 1400 & 30 & 21 & 58.28 & 12.8504 & 52.11 & 36.20 & $2.71 \times 10^{-7}$ & 5.922 \\
\hline FSW02 & 1200 & 30 & 18 & 61.92 & 14.2677 & 55.36 & 33.50 & $3.43 \times 10^{-7}$ & 1.706 \\
\hline FSW03 & 1600 & 45 & 21 & 60.28 & 13.3543 & 53.90 & 40.56 & $2.16 \times 10^{-7}$ & 9.196 \\
\hline FSW04 & 1200 & 60 & 18 & 53.91 & 11.4488 & 48.20 & 32.50 & $1.80 \times 10^{-7}$ & 2.518 \\
\hline FSW05 & 1400 & 45 & 18 & 51.60 & 11.1339 & 46.13 & 31.04 & $1.26 \times 10^{-7}$ & 1.414 \\
\hline FSW06 & 1600 & 60 & 18 & 58.62 & 13.2441 & 52.41 & 36.74 & $2.52 \times 10^{-7}$ & 11.215 \\
\hline FSW07 & 1400 & 60 & 15 & 54.84 & 13.5392 & 49.03 & 27.78 & $1.98 \times 10^{-7}$ & 8.059 \\
\hline FSW08 & 1400 & 30 & 15 & 56.99 & 8.4409 & 50.95 & 31.74 & $1.98 \times 10^{-7}$ & 10.250 \\
\hline FSW09 & 1400 & 60 & 21 & 49.83 & 10.8031 & 44.55 & 38.96 & $2.52 \times 10^{-7}$ & 10.255 \\
\hline FSW10 & 1600 & 45 & 15 & 44.47 & 9.2000 & 39.76 & 34.66 & $4.15 \times 10^{-7}$ & 4.285 \\
\hline FSW11 & 1200 & 45 & 21 & 62.20 & 14.4882 & 55.62 & 36.56 & $1.98 \times 10^{-7}$ & 6.477 \\
\hline FSW12 & 1600 & 30 & 18 & 37.29 & 5.6384 & 33.34 & 35.92 & $2.34 \times 10^{-7}$ & 6.702 \\
\hline FSW13 & 1200 & 45 & 15 & 52.10 & 11.4520 & 46.58 & 32.34 & $7.39 \times 10^{-7}$ & 9.914 \\
\hline BM & & & & 111.84 & 22.8814 & & 40.78 & $3.24 \times 10^{-7}$ & 11.320 \\
\hline
\end{tabular}

Radial basis functions $\mathrm{RBF}_{1^{\prime}}, \mathrm{RBF}_{2^{\prime}} \mathrm{RBF}_{3^{\prime}} \mathrm{RBF}_{4^{\prime}} \mathrm{RBF}_{5^{\prime}} \mathrm{RBF}_{6}$ were developed with a multiquadratic kernel and regularization parameter of 0.0001. The parameters for the radial basis functions $\mathrm{RBF}_{1^{\prime}}, \mathrm{RBF}_{2^{\prime}}, \mathrm{RBF}_{3^{\prime}} \mathrm{RBF}_{4^{\prime}} \mathrm{RBF}_{5^{\prime}} \mathrm{RBF}_{6}$ are given in Table 5. The developed models were assessed to determine their prediction efficiency based on statistical parameters, i.e. the coefficient of determination $\left(R^{2}\right)$, the adjusted coefficient of determination (adj. $R^{2}$ ), and root mean squared error (RMSE). The closeness of RMSE value to $0, R^{2}$ to 1 , and the equivalence of $R^{2}$ and adj. $R^{2}$ indicate that the developed model is efficient in prediction (Cavazutti, 2013; Eriksson et al., 2000; Park, 2007). The statistical parameters for the developed models are given in Table 6 . Table 6 clearly 
a)

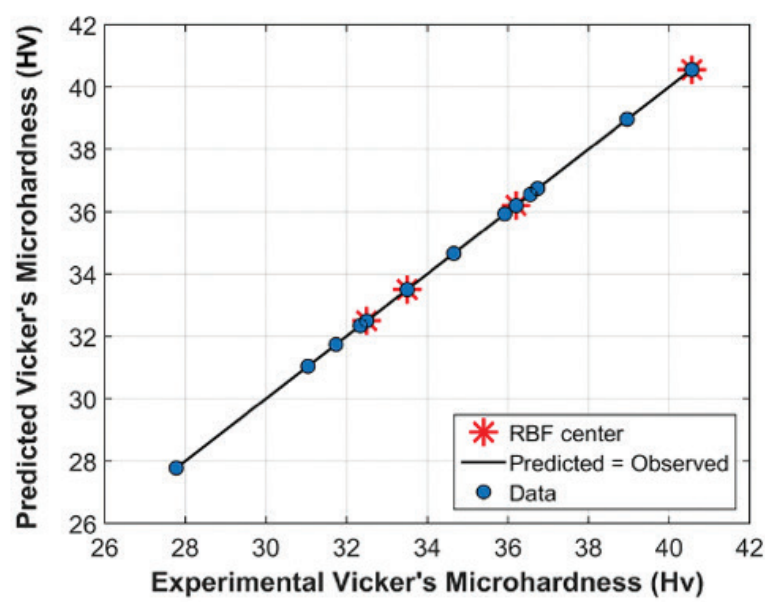

c)

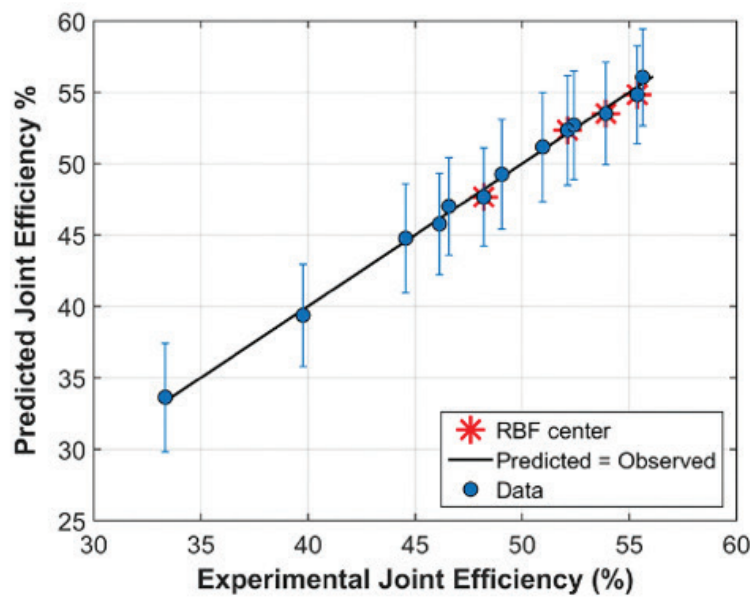

e)

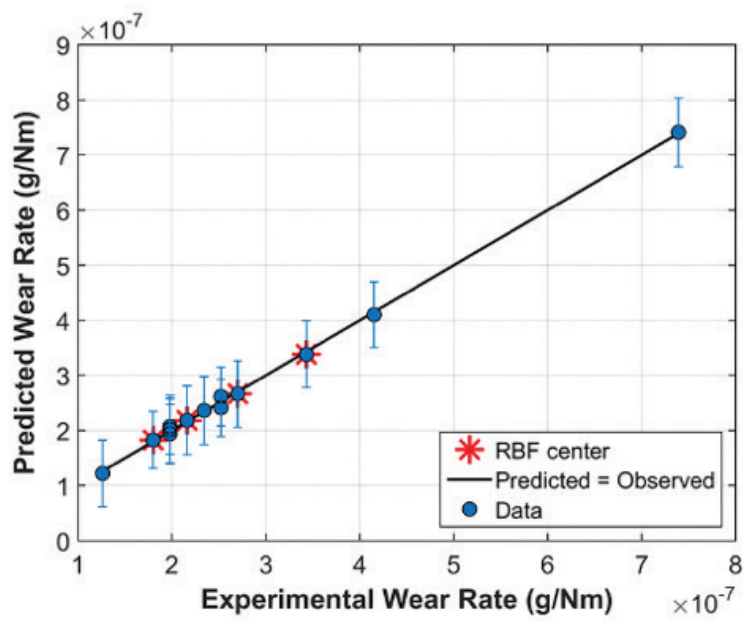

b)

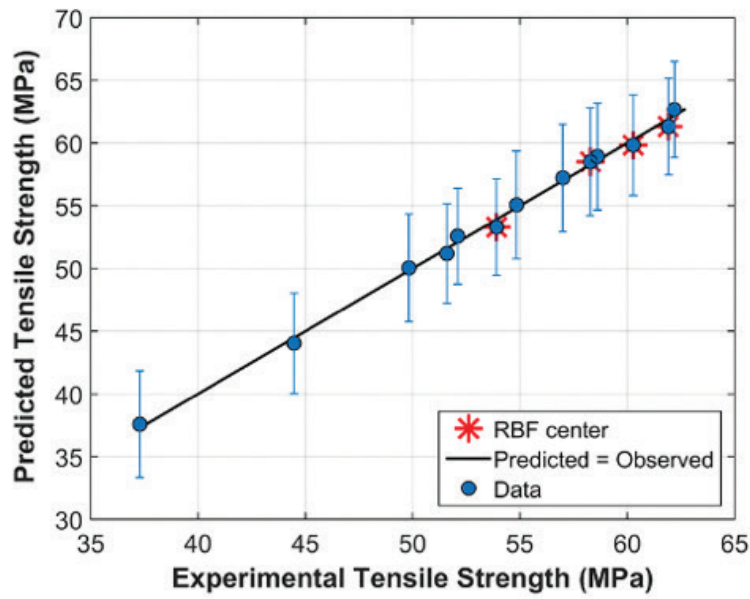

d)

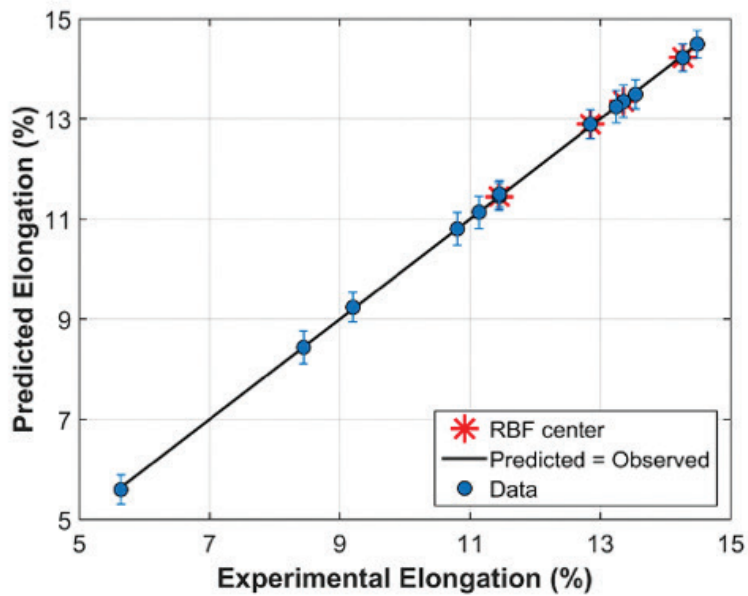

f)

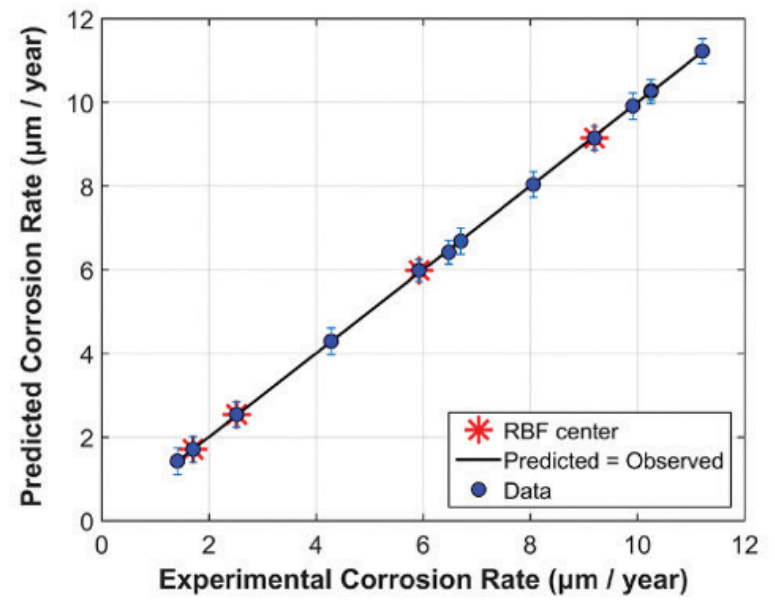

Figure 10.

Plot of experimental vs predicted values of (a) microhardness; (b) tensile strength; (c) joint efficiency; (d) \% elongation; (e) wear sate; (f) corrosion rate. 
Table 5.

Radial basis function parameters in the developed models.

\begin{tabular}{llll} 
SI. & RBF & Centers & Global width \\
\hline 1 & $\mathrm{RBF}_{1}$ & 4 & 0.029147 \\
\hline 2 & $\mathrm{RBF}_{2}$ & 4 & 0.00011911 \\
\hline 3 & $\mathrm{RBF}_{3}$ & 4 & 0.00011911 \\
\hline 4 & $\mathrm{RBF}_{4}$ & 4 & 0.00011911 \\
\hline 5 & $\mathrm{RBF}_{5}$ & 4 & 0.6216 \\
\hline 6 & $\mathrm{RBF}_{6}$ & 4 & 0.00011911 \\
\hline
\end{tabular}

shows that the $R^{2}$ value is close to 1 , that $R^{2}$, and adj. $R^{2}$ values are equal, and that RMSE values are close to 0 . Therefore, the predictions of the developed models are statistically significant. A linear trend was observed between the experimental and predicted values of microhardness, tensile strength, joint efficiency, elongation, corrosion rate, and wear rate, as shown in Figure 10. The linearity of the graphs is indicative of the high prediction efficiency of the developed models. These statistically significant models were utilized to study the influence of friction stir welding process parameters on the microhardness, tensile strength, joint efficiency, elongation, corrosion rate, and wear rate, which are discussed in the following section.

Table 6.

Statistical summary of the developed models.

\begin{tabular}{lllll}
\multirow{2}{*}{ Sl. } & Model & \multicolumn{2}{l}{ Statistical summary of the developed models } & Adj R2 \\
\cline { 3 - 5 } & & RMSE & R2 & 0.999989 \\
\hline 1 & Microhardness & 0.01148 & 0.999908 & 0.979229 \\
\hline 2 & Tensile strength & 1.032178 & 0.996351 & 0.979286 \\
\hline 3 & Joint efficiency & 0.921775 & 0.99636 & 0.999124 \\
\hline 4 & Elongation & 0.075804 & 0.999818 & 0.999511 \\
\hline 5 & Corrosion rate & 0.075755 & 0.998898 & 0.991261 \\
\hline 6 & Wear rate & $1.46 \mathrm{E}-08$ & 0.998245 & \\
\hline
\end{tabular}

\subsection{The Influence of Friction Stir Welding Process Parameters on Microhardness}

The influence of tool rotation speed, welding speed, and shoulder diameter on the microhardness of the friction stir welded specimens is shown in Figure 11. Figure 11 (a) shows the effect of tool rotation speed and welding speed at shoulder diameter of $18 \mathrm{~mm}$ on the microhardness of the welded specimens. Figure 11 (b) shows the effect of tool rotation speed and shoulder diameter at the welding speed of $45 \mathrm{~mm} / \mathrm{min}$ on the microhardness of the welded specimens. Figure 11 (c) shows the effect of welding speed and shoulder diameter at the tool rotation speed of 1400 rpm on the microhardness of the welded specimens.
The summary of the contour plots is given in Table 7. The following results are deduced from the contour plots.

- Friction stir welding of specimens at the tool rotation speed of $1400 \mathrm{rpm}$, welding speed between 55 and $60 \mathrm{~mm} / \mathrm{min}$ and shoulder diameter between 15 and $15.5 \mathrm{~mm}$ resulted in the lowest microhardness.

- $\quad$ Friction stir welding of specimens at tool rotation speed between $1500 \mathrm{rpm}$ and $1600 \mathrm{rpm}$, welding speed $45 \mathrm{~mm} / \mathrm{min}$, and shoulder diameter between $20 \mathrm{~mm}$ and $21 \mathrm{~mm}$ resulted in the highest microhardness. 

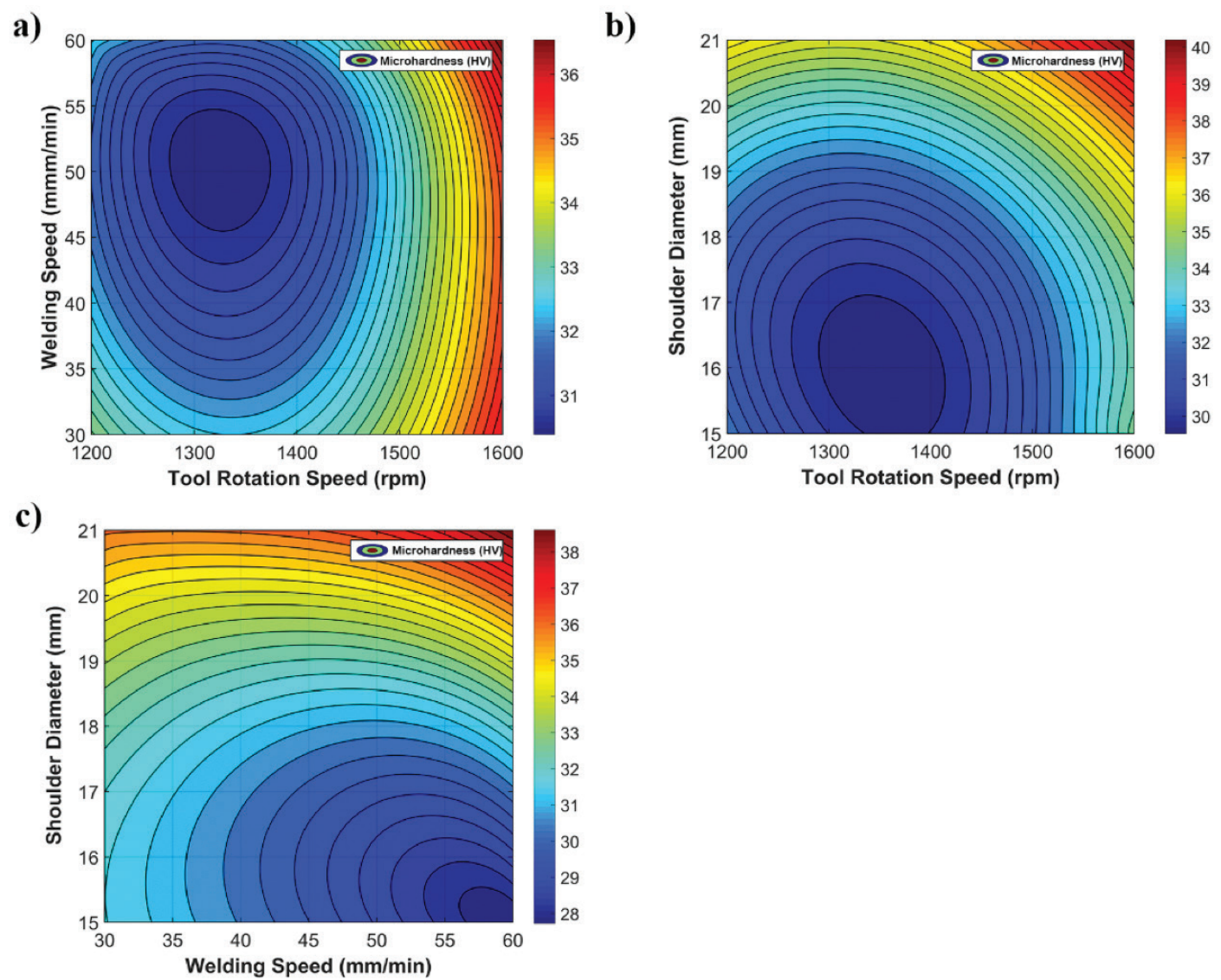

Figure 11.

Effect of friction stir welding process parameters on microhardness (a) tool rotation speed and welding speed; (b) tool rotation speed and shoulder diameter; (c) welding speed and shoulder diameter.

Table 7.

Summary of microhardness contour plots.

SI. Reference

Process Parameter range

Microhardness (HV)

Tool rotation speed $(\mathrm{rpm}) \quad$ Tool traverse speed $(\mathrm{mm} / \mathrm{min}) \quad$ Shoulder diameter $(\mathrm{mm})$

\begin{tabular}{|c|c|c|c|c|c|c|c|c|c|}
\hline & \multirow{2}{*}{\multicolumn{2}{|c|}{ Range }} & \multirow{2}{*}{\multicolumn{2}{|c|}{ Range }} & \multirow{2}{*}{\multicolumn{2}{|c|}{ Range }} & & \\
\hline & & & & & & & & & \\
\hline 1 & Figure 11 (a) & 1300 & 1400 & 45 & 55 & & & Minimum & 30 and 31 \\
\hline 2 & Figure11 (a) & 1550 & 1600 & 30 & 60 & & & Maximum & 35 and 37 \\
\hline 3 & Figure 11 (b) & 1300 & 1400 & & 45 & 15 & 17 & Minimum & 30 and 31 \\
\hline 4 & Figure 11 (a) & 1500 & 1600 & & 45 & 20 & 21 & Maximum & 38 and 40 \\
\hline 5 & Figure 11 (c) & & & 55 & 60 & 15 & 15.5 & Minimum & 28 and 29 \\
\hline 6 & Figure 11 (c) & & & 55 & 60 & 20 & 21 & Maximum & 37 and 38 \\
\hline
\end{tabular}




\subsection{Influence of Friction Stir Welding Process Parameters on Tensile Strength}

The influence of tool rotation speed, welding speed, and shoulder diameter on the tensile strength of the friction stir welded specimens is shown in Figure 12. Figure 12 (a) shows the effect of tool rotation speed and welding speed at shoulder diameter of $18 \mathrm{~mm}$ on the tensile strength of the welded specimens. Figure 12 (b) shows the effect of tool rotation speed and shoulder diameter at the welding speed of $45 \mathrm{~mm} / \mathrm{min}$ on the tensile strength of the welded specimens. Figure 12 (c) shows the effect of welding speed and shoulder diameter at the tool rotation speed of $1400 \mathrm{rpm}$ on the tensile strength of the welded specimens.

The contour plot summary is given in Table 8. The following results have been deduced from contour plots.

- $\quad$ Friction stir welding of specimens at the tool rotation speed between $1500 \mathrm{rpm}$ and $1600 \mathrm{rpm}$, welding speed between 30 $\mathrm{mm} / \mathrm{min}$ and $35 \mathrm{~mm} / \mathrm{min}$, and shoulder diameter of $18 \mathrm{~mm}$ resulted in the lowest tensile strength.

- $\quad$ Friction stir welding of specimens at the tool rotation speed between $1200 \mathrm{rpm}$ and $1250 \mathrm{rpm}$, welding speed of $45 \mathrm{~mm} / \mathrm{min}$, and shoulder between $20 \mathrm{~mm}$ and $21 \mathrm{~mm}$ resulted in the highest tensile strength. a)

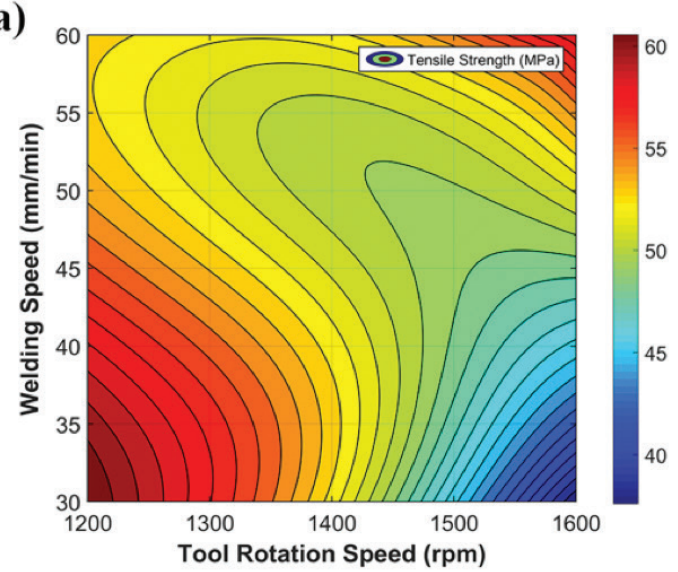

c)

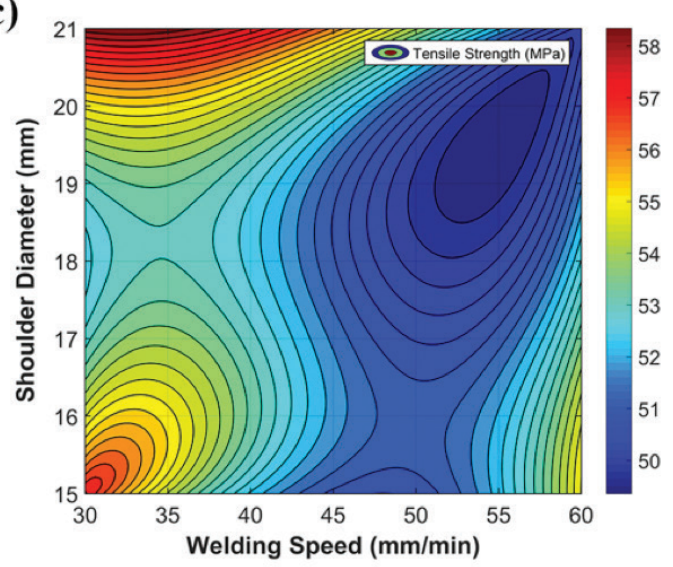

b)

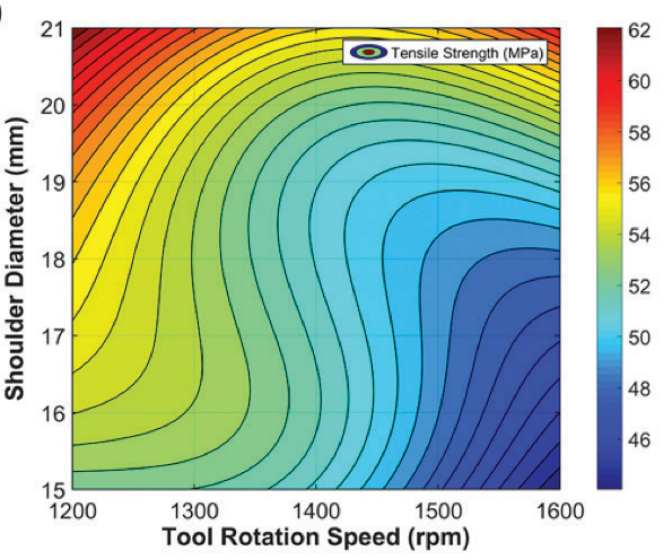

Figure 12.

Effect of friction stir welding process parameters on tensile strength (a) tool rotation speed and welding speed; (b) tool rotation speed and shoulder diameter; (c) welding speed and shoulder diameter. 
Table 8.

Summary of tensile strength contour plots.

SI. Reference

Process parameter range

Tensile strength (MPa)

Tool rotation speed $(\mathrm{rpm}) \quad$ Tool traverse speed $(\mathrm{mm} / \mathrm{min}) \quad$ Shoulder diameter $(\mathrm{mm})$

\begin{tabular}{|c|c|c|c|c|c|c|c|c|c|}
\hline & & \multicolumn{2}{|c|}{ Range } & \multicolumn{2}{|r|}{ Range } & \multicolumn{2}{|c|}{ Range } & \multirow[b]{2}{*}{ Minimum } & \multirow[b]{2}{*}{35 and 40} \\
\hline 1 & Figure $12(\mathrm{a})$ & 1500 & 1600 & 30 & 35 & & & & \\
\hline 2 & Figure $12(\mathrm{a})$ & 1200 & 1250 & 30 & 35 & & & Maximum & 58 and 60 \\
\hline 3 & Figure 12 (b) & 1550 & 1600 & & 45 & 15 & 15.5 & Minimum & 45 and 46 \\
\hline 4 & Figure $12(b)$ & 1200 & 1250 & & 45 & 20 & 21 & Maximum & 60 and 62 \\
\hline 5 & Figure 12 (c) & & & 50 & 55 & 19 & 21 & Minimum & 49 and 50 \\
\hline 6 & Figure 12 (c) & & & 30 & 40 & 20.5 & 21 & Maximum & 57 and 58 \\
\hline
\end{tabular}

\subsection{Influence of Friction Stir Welding Process Parameters on Joint Efficiency}

The influence of tool rotation speed, welding speed, and shoulder diameter on the joint efficiency of the friction stir welded specimens is shown in Figure 13. Figure 13 (a) shows the effect of tool rotation speed and welding speed at shoulder diameter of $18 \mathrm{~mm}$ on the joint efficiency of the welded specimens. Figure 13 (b) shows the effect of tool rotation speed and shoulder diameter at a welding speed of $45 \mathrm{~mm} / \mathrm{min}$ on the joint efficiency of the welded specimens. Figure 13 (c) shows the effect of welding speed and shoulder diameter at the tool rotation speed of 1400 rpm on the joint efficiency of the welded specimens.
The contour plot summary is given in Table 9. The following results have been deduced from the contour plots.

- $\quad$ Friction stir welding of specimens at the tool rotation speed between $1500 \mathrm{rpm}$ and $1600 \mathrm{rpm}$, welding speed between 30 $\mathrm{mm} / \mathrm{min}$ and $40 \mathrm{~mm} / \mathrm{min}$, and shoulder diameter of $18 \mathrm{~mm}$ resulted in the lowest joint efficiency.

- $\quad$ Friction stir welding of specimens at the tool rotation speed between $1200 \mathrm{rpm}$ and $1250 \mathrm{rpm}$, welding speed of $45 \mathrm{~mm} / \mathrm{min}$, and shoulder between $20 \mathrm{~mm}$ and $21 \mathrm{~mm}$ resulted in the highest joint efficiency.

\section{Table 9}

Summary of joint efficiency contour plots.

SI. Reference

Process parameter range

Joint efficiency (\%)

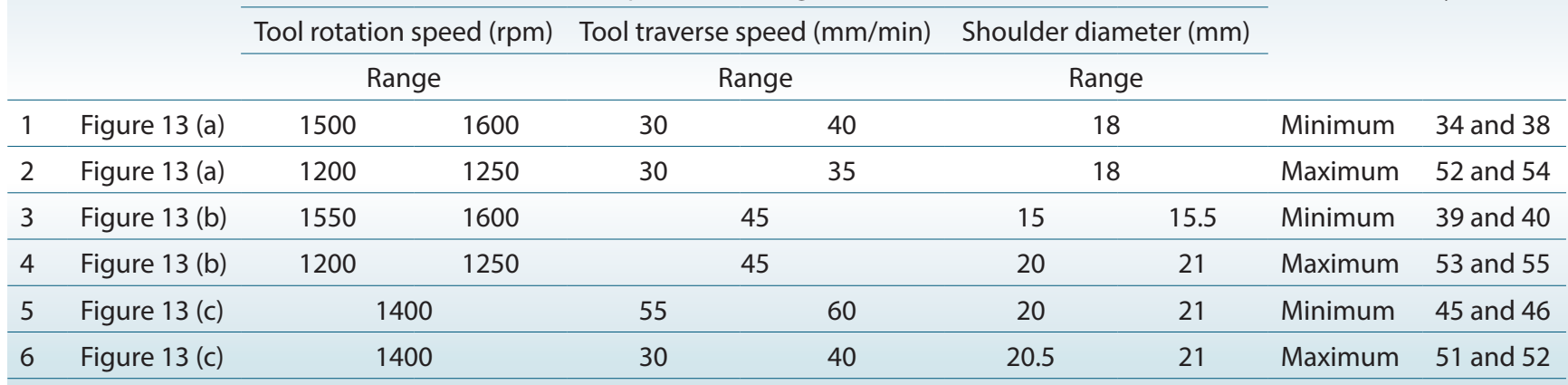


a)

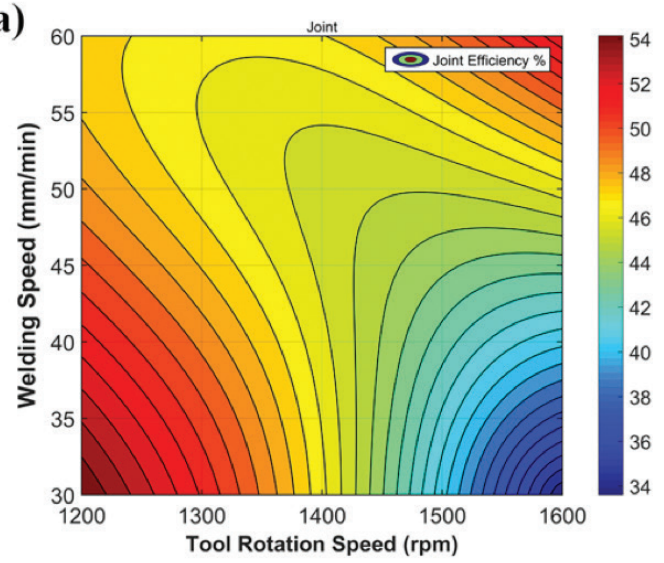

c)

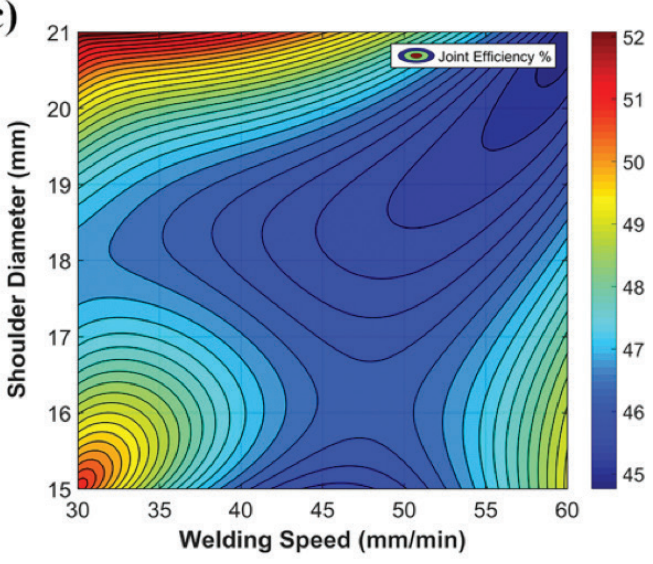

b)

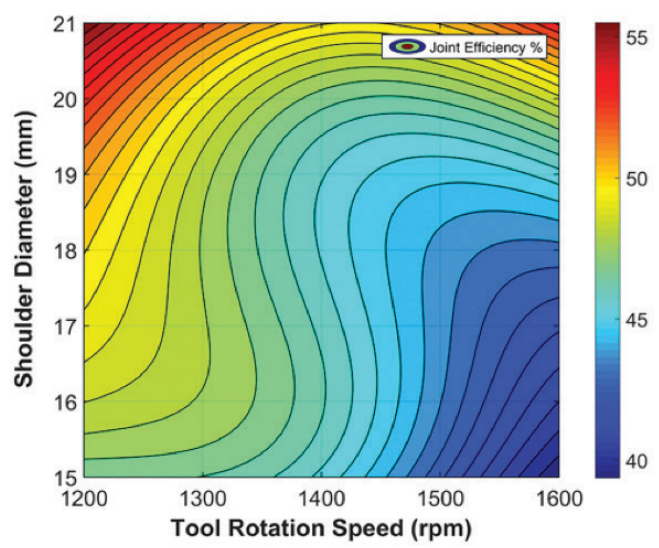

Figure 13.

Effect of friction stir welding process parameters on joint efficiency (a) tool rotation speed and welding speed; (b) tool rotation speed and shoulder diameter; (c) welding speed and shoulder diameter.

\subsection{Influence of Friction Stir Welding Process Parameters on Elongation}

The influence of tool rotation speed, welding speed, and shoulder diameter on the elongation of the friction stir welded specimens is shown in Figure 14. Figure 14 (a) shows the effect of tool rotation speed and welding speed at shoulder diameter of $18 \mathrm{~mm}$ on the elongation of the welded specimens. Figure 14 (b) shows the effect of tool rotation speed and shoulder diameter at a welding speed of $45 \mathrm{~mm} / \mathrm{min}$ on the elongation of the welded specimens. Figure 14 (c) shows the effect of welding speed and shoulder diameter at the tool rotation speed of $1400 \mathrm{rpm}$ on the elongation of the welded specimens.

The contour plot summary is given in Table 10. The following results have been deduced from the contour plots.

- Friction stir welding of specimens at the tool rotation speed between $1500 \mathrm{rpm}$ and $1600 \mathrm{rpm}$, welding speed between 30 $\mathrm{mm} / \mathrm{min}$ and $35 \mathrm{~mm} / \mathrm{min}$, and shoulder diameter of $18 \mathrm{~mm}$ resulted in the lowest elongation.

- Friction stir welding of specimens at the tool rotation speed between $1200 \mathrm{rpm}$ and $1250 \mathrm{rpm}$, welding speed of $45 \mathrm{~mm} / \mathrm{min}$, and shoulder between $20 \mathrm{~mm}$ and $21 \mathrm{~mm}$ resulted in the highest elongation. 
a)

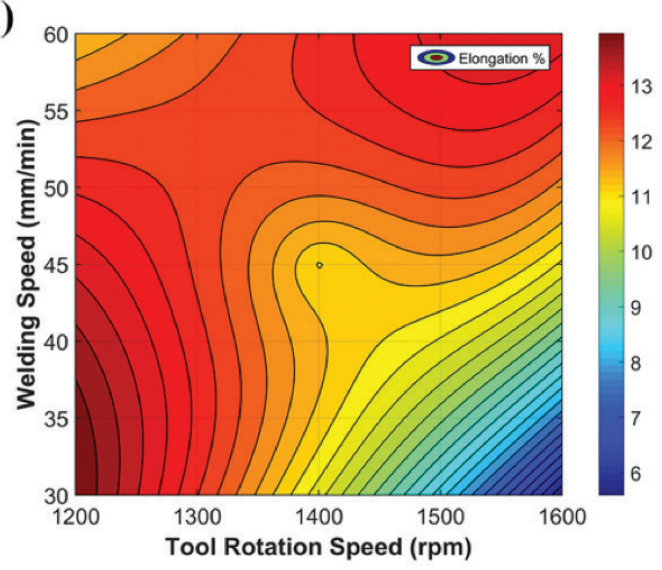

c)

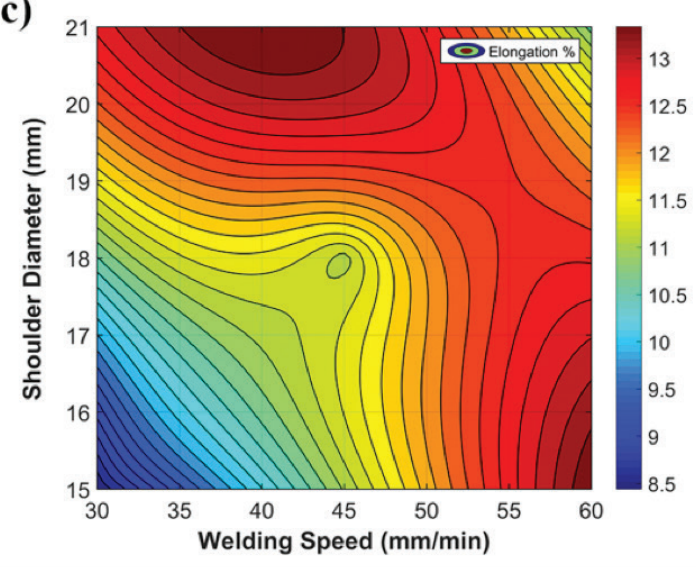

b)

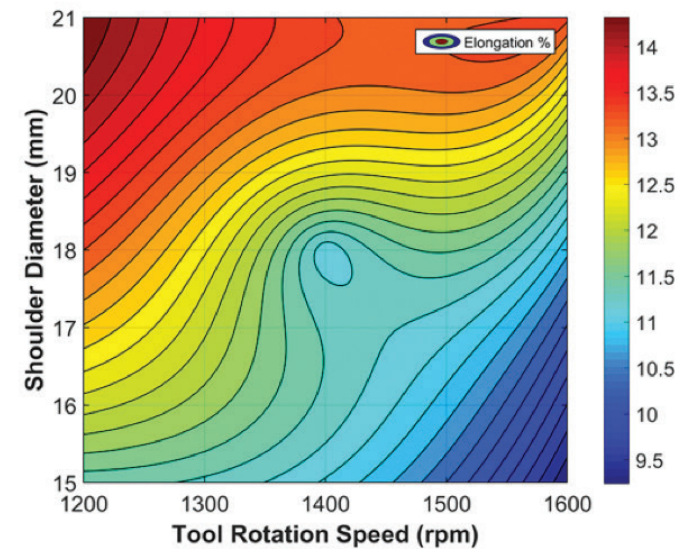

Figure 14.

Effect of friction stir welding process parameters on \% elongation (a) tool rotation speed and welding speed; (b) tool rotation speed and shoulder diameter; (c) welding speed and shoulder diameter.

Table 10.

Summary of elongation contour plots.

SI. Reference

Process parameter range

Elongation (\%)

Tool rotation speed (rpm) Tool traverse speed $(\mathrm{mm} / \mathrm{min}) \quad$ Shoulder diameter $(\mathrm{mm})$

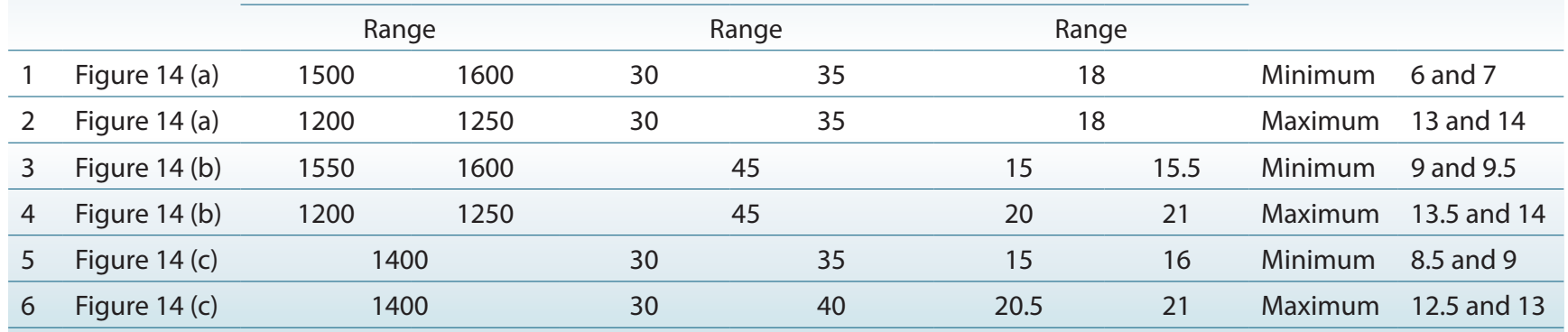




\subsection{Influence of Friction Stir Welding Process Parameters on Wear Rate}

The influence of tool rotation speed, welding speed, and shoulder diameter on the wear rate of the friction stir welded specimens is shown in Figure 15. Figure 15 (a) shows the effect of tool rotation speed and welding speed at shoulder diameter of $18 \mathrm{~mm}$ on the wear rate of the welded specimens. Figure 15 (b) shows the effect of tool rotation speed and shoulder diameter at the welding speed of $45 \mathrm{~mm} / \mathrm{min}$ on the wear rate of the welded specimens. Figure 15 (c) shows the effect of welding speed and shoulder diameter at the tool rotation speed of $1400 \mathrm{rpm}$ on the wear rate of the welded specimens.

The contour plot summary is given in Table 11. The following results have been deduced from the contour plots.

- $\quad$ Friction stir welding of specimens at the tool rotation speed between $1400 \mathrm{rpm}$ and $1500 \mathrm{rpm}$, welding speed of $45 \mathrm{~mm} / \mathrm{min}$, and shoulder diameter between $18 \mathrm{~mm}$ and $20 \mathrm{~mm}$ resulted in the lowest wear rate.

- $\quad$ Friction stir welding of specimens at the tool rotation speed between $1200 \mathrm{rpm}$ and $1250 \mathrm{rpm}$, welding speed of $45 \mathrm{~mm} / \mathrm{min}$, and shoulder between $15 \mathrm{~mm}$ and $16 \mathrm{~mm}$ resulted in the highest wear rate. a)
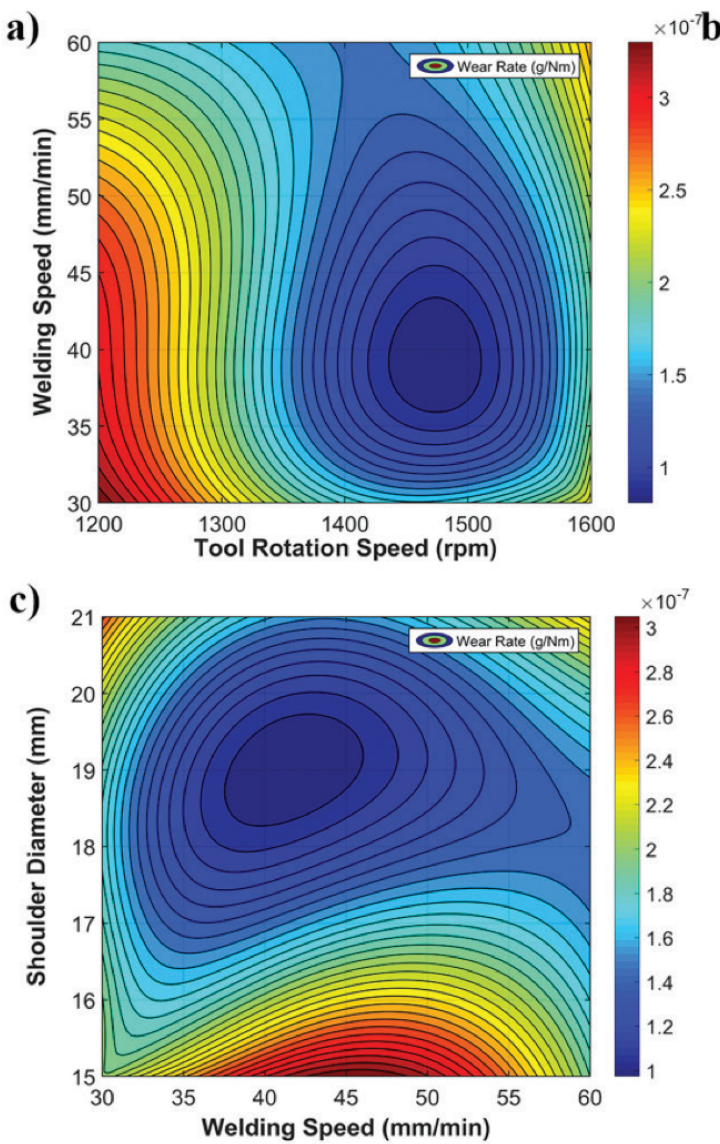

b)

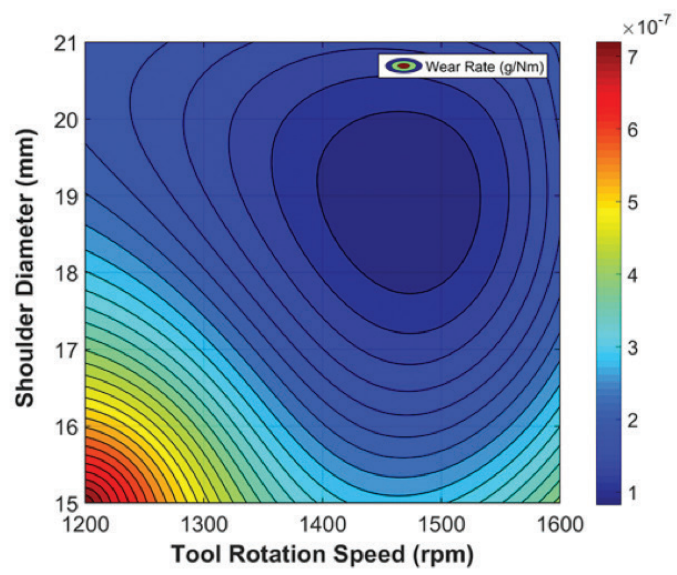

Figure 15.

Effect of friction stir welding process parameters on wear rate ((a) tool rotation speed and welding speed; (b) tool rotation speed and shoulder diameter; (c) welding speed and shoulder diameter. 
Table 11.

Summary of wear rate contour plots.

SI. Reference

Process parameter range

Wear rate $(\mathrm{g} / \mathrm{Nm})$

Tool rotation speed $(\mathrm{rpm})$ Tool traverse speed $(\mathrm{mm} / \mathrm{min}) \quad$ Shoulder diameter $(\mathrm{mm})$

\begin{tabular}{|c|c|c|c|c|c|c|c|c|c|}
\hline & & \multicolumn{3}{|c|}{ Range } & \multirow{2}{*}{$\begin{array}{c}\text { Range } \\
45\end{array}$} & \multicolumn{2}{|c|}{ Range } & & \\
\hline 1 & Figure 15 (a) & 1400 & 1500 & 35 & & 18 & & Minimum & 0.5 and 1.0 \\
\hline 2 & Figure $15(\mathrm{a})$ & 1200 & 1250 & 30 & 35 & 18 & & Maximum & 3.0 and 3.5 \\
\hline 3 & Figure 15 (b) & 1400 & 1500 & 45 & & 18 & 20 & Minimum & Less than 1.0 \\
\hline 4 & Figure 15 (b) & 1200 & 1250 & 45 & & 15 & 16 & Maximum & 6.5 and 7.0 \\
\hline 5 & Figure 15 (c) & 1400 & & 40 & 45 & 18 & 20 & Minimum & 1.0 and 1.2 \\
\hline 6 & Figure 15 (c) & 1400 & & 40 & 50 & 15 & 15.5 & Maximum & 2.8 and 3.0 \\
\hline
\end{tabular}

\subsection{Influence of Friction Stir Welding Process Parameters on Corrosion Rate}

The influence of tool rotation speed, welding speed, and shoulder diameter on the corrosion rate of the friction stir welded specimens is shown in Figure 16. Figure 16 (a) shows the effect of tool rotation speed and welding speed at shoulder diameter of $18 \mathrm{~mm}$ on the corrosion rate of the welded specimens. Figure 16 (b) shows the effect of tool rotation speed and shoulder diameter at the welding speed of $45 \mathrm{~mm} / \mathrm{min}$ on the corrosion rate of the welded specimens. Figure 16 (c) shows the effect of welding speed and shoulder diameter at the tool rotation speed of 1400 rpm on the corrosion rate of the welded specimens.

The contour plot summary is given in Table 12. The following results have been deduced from the contour plots.

- $\quad$ Friction stir welding of specimens at the tool rotation speed between $1200 \mathrm{rpm}$ and $1400 \mathrm{rpm}$, welding speed of $35 \mathrm{~mm} / \mathrm{min}$ and $45 \mathrm{~mm} / \mathrm{min}$, and shoulder diameter between 17.5 and 19.5 resulted in the lowest corrosion rate.

- $\quad$ Friction stir welding of specimens at the tool rotation speed between $1550 \mathrm{rpm}$ and $1600 \mathrm{rpm}$, welding speed between 55 $\mathrm{mm} / \mathrm{min}$ and $60 \mathrm{~mm} / \mathrm{min}$, and $18 \mathrm{~mm}$ shoulder resulted in the highest corrosion wear rate.

Table 12.

Summary of corrosion rate contour plots

SI. Reference

Process parameter range

Corrosion rate ( $\mu \mathrm{m} /$ year)

Tool rotation speed (rpm) Tool traverse speed $(\mathrm{mm} / \mathrm{min}) \quad$ Shoulder diameter $(\mathrm{mm})$

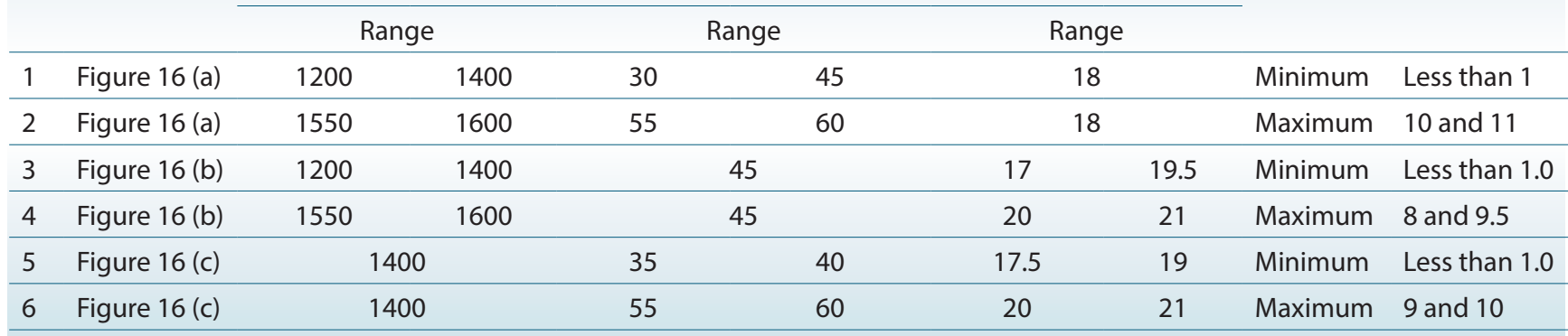


a)

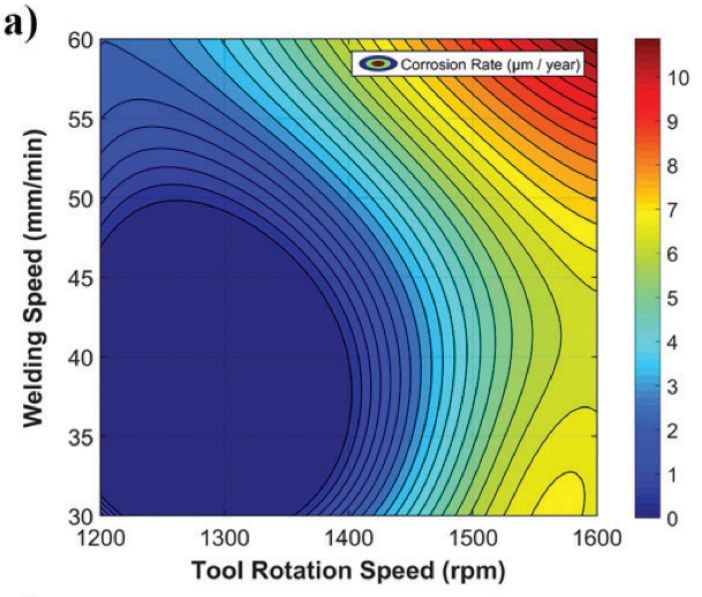

c)

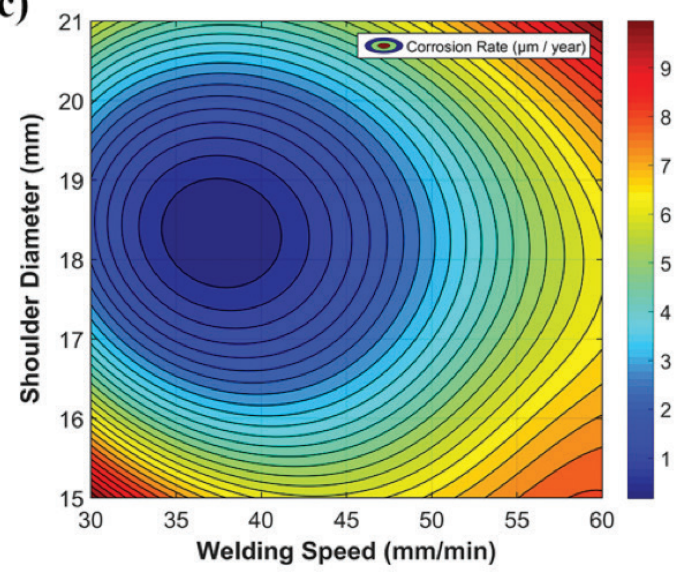

b)

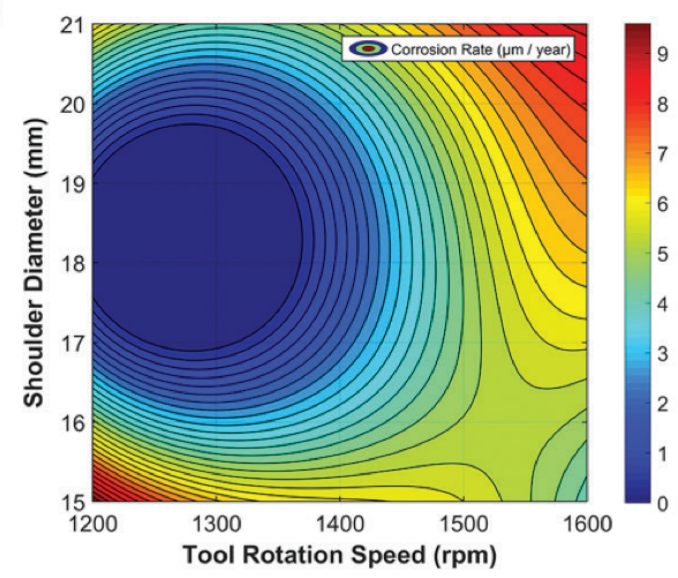

Figure 16.

Effect of friction stir welding process parameters on corrosion rate (a) tool rotation speed and welding speed; (b) tool rotation speed and shoulder diameter; (c) welding speed and shoulder diameter.

\section{CONCLUSION}

Aluminum alloy AA8011 plates were successfully joined using the friction stir welding process. Friction stir welding tests were conducted on AA8011 by varying tool rotation speed, welding speed, and tool shoulder diameter. The joined plates were subjected to tensile test, wear test, and corrosion test. Quadratic - Radial Basis Function models were developed to correlate the friction stir welding process parameters with joint properties. The statistical parameters have verified the high effectiveness of the developed models. The results are as follows: - $\quad$ Friction stir welding is an effective methodology for joining aluminum alloy 8011 and properties are appreciably affected by friction stir welding process parameters.

- Friction stir welding of a specimen at $1200 \mathrm{rpm}, 45 \mathrm{~mm} /$ $\mathrm{min}, 21 \mathrm{~mm}$ resulted in the maximum ultimate tensile strength of $62.20 \mathrm{MPa}$, with the high joint efficiency of $55.62 \%$.
- The microhardness of aluminum alloy 8011 was found to be $41.6 \mathrm{HV}$. Friction stir welding of a specimen at $1600 \mathrm{rpm}, 45$ $\mathrm{mm} / \mathrm{min}, 21 \mathrm{~mm}$ resulted in the high hardness (40.56 HV) in the nugget zone among the tested specimens. However, joint strength was $\sim 2 \%$ lower than measured in specimen FSW11.

- The wear rate of aluminum alloy 8011 is $3.24 \times 10^{-07} \mathrm{~g} /$ $\mathrm{Nm}$. Specimen FSW05 (welded at $1400 \mathrm{rpm}, 45 \mathrm{~mm} / \mathrm{min}$, and $18 \mathrm{~mm}$ ) had the low wear rate of $1.26 \times 10^{-07} \mathrm{~g} / \mathrm{Nm}$. The results of the immersion corrosion test show that specimen FSW05 had the lowest corrosion rate of $0.0014 \mathrm{~mm} /$ year among the tested specimens.

- $\quad$ Based on joint efficiency as primary constraint, optimum process parameters for friction stir welding of aluminum alloy AA8011 have been established as follows: tool rotation speed of $1200 \mathrm{rpm}$, tool traverse speed of $45 \mathrm{~mm} / \mathrm{min}$, and tool shoulder diameter of $21 \mathrm{~mm}$. 


\section{REFERENCES}

Akca, E. \& Gürsel, A., 2016. Solid State Welding and Application in Aeronautical Industry. Periodicals of Engineering and Natural Sciences (PEN), 4(1). Available at: http://dx.doi.org/10.21533/pen.v4i1.46.

Akinlabi, E.T. \& Mahamood, R.M., 2020. Introduction to Friction Welding, Friction Stir Welding and Friction Stir Processing. Solid-State Welding: Friction and Friction Stir Welding Processes, pp.1-12. Available at: http://dx.doi.org/10.1007/978-3-030-37015-2 1.

Anil Kumar, R. et al., 2019. Investigations on the Tribological Properties of HeatTreated Copper Composite Using Hybrid Quadratic-Radial Basis Function Model. Transactions of the Indian Institute of Metals, 72(12), pp.3117-3128. Available at: http://dx.doi.org/10.1007/s12666-019-01777-y.

Ashwin, A. et al., 2019. Predicting the Wear Rate of Aluminum Alloy AA2024-T35 using Hybrid Linear function and Radial Basis Function. IOP Conference Series: Materials Science and Engineering, 561, p.012046. Available at: http://dx.doi.org/10.1088/1757-899x/561/1/012046.

Barath, V.R., Vaira Vignesh, R. \& Padmanaban, R., 2018. Analysing the strength of friction stir welded dissimilar aluminium alloys using Sugeno Fuzzy model. IOP Conference Series: Materials Science and Engineering, 310, p.012043. Available at: http://dx.doi.org/10.1088/1757-899x/310/1/012043.

Cavazzuti, M., 2012. Design of Experiments. Optimization Methods, pp.13-42. Available at:

http://dx.doi.org/10.1007/978-3-642-31187-1 2.

Cui, J. et al., 2019. Effects of annealing treatment on mechanical properties of 8011 aluminum alloy after cryogenic rolling. Metallurgical Research \& Technology, 116(2), p.219. Available at: http://dx.doi.org/10.1051/metal/2018067.

Davidson, B.S. \& Neelakrishnan, S., 2018. Influence of Friction Stir Welding Parameters on Tensile Properties of AA8011 Aluminium Alloy Plate. Journal of Computational and Theoretical Nanoscience, 15(1), pp.93-98. Available at: http://dx.doi.org/10.1166/jctn.2018.7060.

Eriksson, L. et el., 2000. Design of experiments, Principles and Applications. Learn ways $A B$, Stockholm.

Ghetiya, N.D., Patel, K.M. \& Kavar, A.J., 2015. Multi-objective Optimization of FSW Process Parameters of Aluminium Alloy Using Taguchi-Based Grey Relational Analysis. Transactions of the Indian Institute of Metals, 69(4), pp.917-923. Available at: http://dx.doi.org/10.1007/s12666-015-0581-1.

Ilangovan, S. et al., 2018. Comparison of Statistical and Soft Computing Models for Predicting Hardness and Wear Rate of Cu-Ni-Sn Alloy. Progress in Computing, Analytics and Networking, pp.559-571. Available at:

http://dx.doi.org/10.1007/978-981-10-7871-2 54

Magibalan, S. et al., 2018. Dry sliding behavior of the aluminum alloy 8011 composite with $8 \%$ fly ash. Materials Testing, 60(7-8), pp.777-782. Available at: http://dx.doi.org/10.3139/120.111213.

Malekimoghadam, R. \& Icardi, U., 2019. Prediction of mechanical properties of carbon nanotube carbon fiber reinforced hybrid composites using multi-scale finite element modelling. Composites Part B: Engineering, 177, p.107405. Available at: http://dx.doi.org/10.1016/j.compositesb.2019.107405.

Mandal, N.R., 2017. Ship Construction and Welding. Springer Series on Naval Architecture, Marine Engineering, Shipbuilding and Shipping. Available at: http://dx.doi.org/10.1007/978-981-10-2955-4.
Midling, O. T. , Morley, E. J., \& Sandvik, A., 1998. Friction stir welding, ed. Google Patents.

Mishra, R.K., 2020. Study the effect of pre-corrosion on mechanical properties and fatigue life of aluminum alloy 8011. Materials Today: Proceedings, 25, pp.602-609. Available at:

http://dx.doi.org/10.1016/j.matpr.2019.07.375

Mishra, R.S. \& Ma, Z.Y., 2005. Friction stir welding and processing. Materials Science and Engineering: R: Reports, 50(1-2), pp.1-78. Available at: http://dx.doi.org/10.1016/j.mser.2005.07.001.

Murugan, B.K. et al., 2018. Study of the effect of parameters in friction surfacing of Monel over Mild Steel using linear - radial basis function model. Materials Today: Proceedings, 5(2), pp.8604-8611. Available at: http://dx.doi.org/10.1016/j.matpr.2017.11.558.

Nandan, R., DebRoy, T. \& Bhadeshia, H., 2008. Recent advances in friction-stir welding - Process, weldment structure and properties. Progress in Materials Science, 53(6), pp.980-1023. Available at: http://dx.doi.org/10.1016/j.pmatsci.2008.05.001.

Palani, K. et al., 2018a. Effect of welding parameters on mechanical properties of dissimilar Friction Stir Processed AA 8011 and AA 5083-H321 aluminium alloys. IOP Conference Series: Materials Science and Engineering, 390, p.012072. Available at: http://dx.doi.org/10.1088/1757-899x/390/1/012072.

Palani, K. et al., 2018b. Influence of Friction Stir Processing Parameters on Tensile properties and Microstructure of Dissimilar AA 8011-H24 and AA 6061-T6 aluminum alloy joints in Nugget Zone. IOP Conference Series: Materials Science and Engineering, 390, p.012108. Available at: http://dx.doi.org/10.1088/1757-899x/390/1/012108.

Park, G.J., 2007. Design of Experiments. Analytic Methods for Design Practice, pp.309-391. Available at: http://dx.doi.org/10.1007/978-1-84628-473-1 6.

Shehabeldeen, T.A. et al., 2019. Modeling of friction stir welding process using adaptive neuro-fuzzy inference system integrated with harris hawks optimizer. Journal of Materials Research and Technology, 8(6), pp.5882-5892. Available at: http://dx.doi.org/10.1016/j.jmrt.2019.09.060.

Vaira Vignesh, R. \& Padmanaban, R., 2018b. Influence of friction stir processing parameters on the wear resistance of aluminium alloy AA5083. Materials Today: Proceedings, 5(2), pp.7437-7446. Available at: http://dx.doi.org/10.1016/j.matpr.2017.11.415.

Vaira Vignesh, R. \& Ramasamy, P., 2017. Modelling Corrosion Behavior of Friction Stir Processed Aluminium Alloy 5083 Using Polynomial: Radial Basis Function. Transactions of the Indian Institute of Metals, 70(10), pp.2575-2589. Available at: http://dx.doi.org/10.1007/s12666-017-1110-1.S.

Vaira Vignesh, R. et al., 2016. Analysing the strength of friction stir spot welded joints of aluminium alloy by fuzzy logic. IOP Conference Series: Materials Science and Engineering, 149, p.012136. Available at: http://dx.doi.org/10.1088/1757-899x/149/1/012136.

Vaira Vignesh, R., Padmanaban, R. \& Datta, M., 2018a. Influence of FSP on the microstructure, microhardness, intergranular corrosion susceptibility and wear resistance of AA5083 alloy. Tribology - Materials, Surfaces \& Interfaces, 12(3), pp.157-169. Available at: http://dx.doi.org/10.1080/17515831.2018.1483295. 
Vaira Vignesh, R., Padmanaban, R. \& Datta, M., 2018c. Influence of FSP on the microstructure, microhardness, intergranular corrosion susceptibility and wear resistance of AA5083 alloy. Tribology - Materials, Surfaces \& Interfaces, 12(3), pp.157-169. Available at:

http://dx.doi.org/10.1080/17515831.2018.1483295.

Vaira Vignesh, R., Padmanaban, R. \& Govindaraju, M., 2019. Investigations on the surface topography, corrosion behavior, and biocompatibility of friction stir processed magnesium alloy AZ91D. Surface Topography: Metrology and Properties, 7(2), p.025020. Available at:

http://dx.doi.org/10.1088/2051-672x/ab269c.
Vasudevan, A.K. \& Doherty, R.D., 1989. Preface. Aluminum Alloys-Contemporary Research and Applications, Available at:

http://dx.doi.org/10.1016/b978-0-12-341831-9.50005-x.

Vora, J.J. \& Badheka, V.J. eds., 2019. Advances in Welding Technologies for Process Development. Available at:

\section{http://dx.doi.org/10.1201/9781351234825.}

Wahid, M.A. et al., 2016. Friction Stir Welds of Al Alloy-Cu: An Investigation on Effect of Plunge Depth. Archive of Mechanical Engineering, 63(4), pp.619-634. Available at: http://dx.doi.org/10.1515/meceng-2016-0035. 